\title{
Differences of opinion in sovereign credit signals during the European crisis
}

Alsakka, R.; ap Gwilym, O.M.; Vu, Huong

\section{European Journal of Finance}

DOI:

10.1080/1351847X.2016.1177565

Published: 01/01/2017

Peer reviewed version

Cyswllt i'r cyhoeddiad / Link to publication

Dyfyniad o'r fersiwn a gyhoeddwyd / Citation for published version (APA):

Alsakka, R., ap Gwilym, O. M., \& Vu, H. (2017). Differences of opinion in sovereign credit signals during the European crisis. European Journal of Finance, 23, 859-884.

https://doi.org/10.1080/1351847X.2016.1177565

\footnotetext{
Hawliau Cyffredinol / General rights

Copyright and moral rights for the publications made accessible in the public portal are retained by the authors and/or other copyright owners and it is a condition of accessing publications that users recognise and abide by the legal requirements associated with these rights.

- Users may download and print one copy of any publication from the public portal for the purpose of private study or research.

- You may not further distribute the material or use it for any profit-making activity or commercial gain

- You may freely distribute the URL identifying the publication in the public portal ?
}

Take down policy

If you believe that this document breaches copyright please contact us providing details, and we will remove access to the work immediately and investigate your claim. 


\title{
Differences of opinion in sovereign credit signals during the European crisis
}

\author{
Rasha Alsakka ${ }^{\mathrm{a},}$, Owain ap Gwilym ${ }^{\mathrm{a}}$, Huong $\mathrm{Vu}^{\mathrm{b}}$ \\ a Bangor Business School, Bangor University, LL57 2DG, UK \\ ${ }^{\mathrm{b}}$ Coventry Business School, Coventry University, CV1 5FB, UK
}

This version: $4^{\text {th }}$ April 2016

\begin{abstract}
Motivated by the European debt crisis and the new EU regulatory regime for the credit rating industry, we analyse differences of opinion in sovereign credit signals and their influence on European stock markets. Rating disagreements have a significant connection with subsequent negative credit actions by each agency. However, links among Moody's/Fitch actions and their rating disagreements with other agencies have weakened in the post-regulation period. We also find that only S\&P's negative credit signals affect the own-country stock market and spill over to other European markets, but this is concentrated in the pre-regulation period. Stronger stock market reactions occur when S\&P has already assigned a lower rating than Moody's/Fitch prior to taking a further negative action.
\end{abstract}

JEL classification: G15; G24.

Keywords: Sovereign credit signals; Split rating; Stock return; European debt crisis; EU regulation of rating agencies.

* Corresponding author. Tel.: +44 (0) 1248 383571. E-mail address: r.alsakka@bangor.ac.uk 


\section{Introduction}

The recent global financial crisis (GFC) consisted of the banking and sub-prime crises in 2006-2009 and the European debt crisis (EDC) which started in late-2009. The GFC presented challenges for credit rating agencies (CRAs) and triggered increased scrutiny of their performance. During the EDC, CRAs faced pressures from various directions on the timing and severity of downgrade actions (e.g. see IMF, 2010; Powell, 2013). The main aims of this paper are to analyse differences in the negative credit actions of the three largest CRAs during the GFC and to assess their impact on European equity markets. We also examine whether recent EU regulation of CRAs ${ }^{1}$ reveals any effects on the CRAs' negative signals and their market impact. The investigation focuses on sovereign ratings, given their crucial importance from credit market and financial stability perspectives (European Securities and Markets Authority (ESMA), 2013a). Sovereign ratings have a strong influence on other ratings, including those of banks (e.g. Williams et al., 2013) and corporates (e.g. Borensztein et al., 2013). Sovereign credit news can have a strong effect on bond and equity valuations (e.g. Gande and Parsley, 2005; Ferreira and Gama, 2007; Hill and Faff, 2010; Afonso et al., 2012).

Developed sovereigns have historically been assigned high and stable investmentgrade ratings. Prior to the GFC, it was mainly the emerging economies that experienced low credit ratings, ratings instability and split ratings. ${ }^{2}$ However, this situation has changed rapidly in recent years, with ESMA (2013a) noting volatility in European sovereign ratings. During the EDC (especially 2010-2012), many European countries, particularly Greece,

\footnotetext{
${ }^{1}$ In this paper, the term 'recent EU regulation' refers to the establishment of a new regulatory regime in July 2011, when the European Securities and Markets Authority assumed responsibility for European CRA regulation.

${ }^{2}$ Split ratings occur when different CRAs assign unequal ratings to the same issuer at the same time. Prior studies (e.g. Morgan, 2002; Livingston and Zhou, 2010) attribute split ratings to issuers' opaqueness or to different rating methodologies and differing factors used by CRAs in judging issuers' creditworthiness.
} 
Ireland, Italy, Portugal and Spain, suffered from higher borrowing $\operatorname{costs}^{3}$ and serial negative credit signals from CRAs, driven by increased government deficits and debt levels, and weak economic growth (e.g. Moody's, 2011; Fitch, 2012; S\&P, 2012). The deterioration in European sovereign creditworthiness had an adverse impact on European banks' ratings, funding costs, market access and share prices (e.g. Alsakka et al., 2014; Correa et al. 2014; Gennaioli et al., 2014). Split ratings have also been persistent for many high-rated sovereigns, such as Austria, France, and the UK during the EDC. Although some European countries have shown positive sovereign rating trends since the second half of 2013 , they still face challenges arising from indebtedness and restrictive financing conditions.

The rating industry is concentrated among the three largest CRAs. Moody's (S\&P) accounts for $34.8 \%$ (34.6\%) of the market, while Fitch's share is $17.7 \%$ (ESMA, 2013b). Issuers seek multiple ratings to address any information gaps across CRAs, hoping to improve their ratings. Investors are averse to uncertainty, which can be reduced by additional ratings (e.g. Bongaerts et al. 2012; Fabozzi and Vink, 2015). The common practice by financial regulators and academic studies to treat the ratings from major CRAs as equally informative is questionable. Our investigation reveals significant insights on differences among the three CRAs in their assessments of sovereign creditworthiness. It also identifies differences in the manner in which CRAs adjust their ratings, along with differential impact of their actions on European equity markets. Such evidence is highly relevant to the perceptions of markets and regulators about the credibility of these CRAs.

The first research question considers the connection between CRAs' disagreements and subsequent negative sovereign credit signals. This is pertinent during the EDC, when significant divergence in opinion on the creditworthiness of European countries becomes

\footnotetext{
${ }^{3}$ For example, the weekly average yield spreads of ten-year government bonds over German Bunds jumped from below 2 percentage points in 2008 to 32, 12, 7, 5 and 4 percentage points in Greece, Portugal, Ireland, Italy and Spain, respectively, at the end of 2011 (Deutsche Bundesbank, 2012).
} 
discernible. This is the first study to connect the evolution of European sovereign ratings to the prior split ratings (see Section 2.1). Valuable information is captured in split ratings, which can impact the probabilities of subsequent credit actions (e.g. Livingston et al., 2008). Using a daily dataset for 27 European Union (EU) countries for July 2006 to November 2014, we reveal that disagreements in CRA opinions have a significant relation with subsequent negative credit actions by each CRA. This implies that rating differences across the CRAs may improve forecasts of future rating actions. The CRA assigning the superior (inferior) ratings may be anticipated to revise its ratings downwards (upwards). It follows that rating actions which are inconsistent with this can bring surprise content to the financial markets, hence affecting asset prices significantly. Split ratings improve the predictability of downgrade actions on the superior ratings, making those actions less influential upon financial markets.

Hence, we raise a second research question: 'do pre-event split ratings affect the stock markets' reactions to CRAs' negative credit signals?' The originality of this element arises from analysing the equity market impact of negative credit signals from the perspective of split ratings. In this aspect, we focus only on sovereigns with split ratings immediately before a rating action occurs. For a particular event announced by a CRA, the status of its ratings in comparison to other CRAs before the events could either weaken or strengthen the stock price reactions. We anticipate that downgrades on inferior ratings are expected to elicit stronger reactions than downgrades on superior ratings. This second research question is motivated by $\mathrm{Vu}$ et al. (2015) who show that the reactions of sovereign bond spreads to negative credit signals are affected by CRAs' opinion differences. Whereas Vu et al. (2015) study global bond markets during 2000-2012, we examine European stock markets during the GFC. Consistent with the findings of Vu et al. (2015), we report that European stock markets are only significantly responsive to negative credit signals by $\mathrm{S} \& \mathrm{P}$ (the most independent 
CRA in terms of rating actions), and that market responses are affected by disagreements between S\&P and Moody's/Fitch. Specifically, one-notch downgrades by S\&P for a sovereign rated lower by S\&P than by Moody's have a strong significant impact on stock returns (negative abnormal returns of $1.4 \%$ ), but similar actions for a sovereign rated higher by S\&P than Moody's do not have a significant impact. We also reveal that the impact of S\&P's negative signals spills over to stock markets of other European countries. Regional links and European Union membership are very likely to drive such spill-over effects (as highlighted by, e.g., Mongelli (2008), Alter and Beyer (2014) and Harari (2014)).

Our third research question investigates the impact of the recent EU regulation of CRAs operating in Europe. ${ }^{4}$ In response to the role of CRAs at the outset of the GFC, formal EU regulation of CRAs was instigated in December 2009. The aim of this new regime was to maintain confidence in the rating industry, to decrease overreliance on credit ratings and (importantly in our context) to reduce mechanistic market reactions to credit rating signals. In July 2011, supervision of CRAs in Europe was assigned to ESMA, which has the power to take enforcement action. ${ }^{5}$ We investigate whether the impact of split ratings on future negative credit actions (the focus of our first research question), and the effect of split ratings on stock market responses to CRAs' sovereign negative events (the focus of our second research question), vary between pre- and post- EU CRA regulation (with the cut-off in July 2011). There is very sparse prior literature on such issues. ${ }^{6}$ Our investigation provides indicative evidence of the effectiveness of the recent EU regulation in reducing (mechanistic) market reactions. Specifically, we find that the market impact of S\&P negative actions is only

\footnotetext{
${ }^{4}$ This presents a further contribution beyond Vu et al. (2015), who did not address the impact of the EU regulation of CRAs.

${ }^{5}$ Further details are discussed in Section 2.2.

${ }^{6}$ Jorion et al. (2005) and Poon and Evans (2013) study the impact of U.S. Regulation Fair Disclosure (Reg FD) in 2000 on stock markets and bond markets, respectively. Studies on other forms of regulation affecting CRAs relate to periods prior to the EU CRA regulation (e.g. Becker and Milbourn (2011) utilize a U.S. sample from 1995 to 2006).
} 
significant in the pre-regulation period, in line with our findings that connections among the three CRAs' actions are much more evident in the pre-regulation period.

The remainder of the paper is organised as follows. Section 2 reviews the relevant literature. Section 3 describes the data sample, Section 4 presents the methodology, Section 5 analyses the results, and Section 6 concludes the paper.

\section{Key themes associated with the empirical analysis}

\subsection{Rating migrations, split ratings and market impact}

Rating dynamics are crucial for the application of risk management and pricing (Fuertes and Kalotychou, 2007). Estimates of rating migration probabilities are at the core of several risk management tools and credit risk managers utilize CRAs' rating migration information. Hence, understanding the factors which affect the probabilities of rating transition has wide relevance. Rating volatility (i.e. the frequency and size of rating actions) is affected by economic cycles (e.g. Bangia et al., 2002; Livingston et al. 2008), and the period that an issuer remains in a specific rating category (e.g. Fuertes and Kalotychou, 2007). Prior rating changes, outlooks and watch status have predictive power for the direction of future rating transitions by the same CRA (Fuertes and Kalotychou, 2007). Alsakka and ap Gwilym (2010) investigate whether sovereign rating changes by one CRA are affected by prior rating changes by another CRA during August 1994 - June 2009 (wherein most of the actions relate to emerging countries). They find that upgrade (downgrade) probabilities are much higher, and downgrade (upgrade) probabilities are much lower for a sovereign with a recent upgrade (downgrade) by another CRA.

Sovereign credit ratings have become one of fund managers' important considerations. Credit rating signals can trigger re-weighting of assets and impact on market prices. Prior evidence shows that negative sovereign rating signals have a significant impact on equity and bond markets, while positive news has a more limited impact (e.g. Brooks et al., 2004; Gande 
and Parsley, 2005; Hill and Faff, 2010; Afonso et al., 2012). ${ }^{7}$ Ferreira and Gama (2007) investigate the cross-country spill-over effects of sovereign rating changes in international stock markets, and show that rating downgrades (but not upgrades) trigger cross-border effects. Due to the close link between sovereign risk and the operation of the banking system, sovereign rating signals can induce reactions in banks' share prices (Correa et al., 2014). In this literature on the market impact of sovereign credit events, the actions of each CRA are typically examined independently of each other, whereby the effects of split ratings between CRAs are ignored. When one CRA revises their ratings, stock price reactions are likely to be affected by whether a split rating is widening or narrowing.

Prior empirical studies on split ratings have focused on the causes of split ratings and the market perception of corporate default risk associated with split-rated issuers (e.g. Livingston and Zhou, 2010; Bongaerts et al., 2012). Split ratings have a greater tendency to occur for opaque issuers (e.g. Morgan, 2002). Livingston et al. (2008) find that split rated corporates are prone to be upgraded (downgraded) by the CRA from whom a lower (higher) rating exists. ${ }^{8}$ Livingston et al. (2010) show that the pricing of corporate credit risk is exercised based on both the CRA's credit opinions and the opinion differences, where the heavier weight is placed on the more conservative CRA. Bongaerts et al. (2012) highlight that corporates seek a third rating from Fitch as a "tie-breaker" for debt issues which are split rated by S\&P and Moody's. Vu et al. (2015) find that bond market reactions are far stronger for negative signals on the inferior ratings and for positive signals on the superior ratings.

\footnotetext{
${ }^{7}$ To the extent that stock and bond prices are found to respond to credit rating signals, this implies either evidence against the semi-strong form of the Efficient Market Hypothesis or the presence of private information available only to CRAs that is released into the public domain through credit signals (e.g. Brooks et al, 2004). If rating signals did not add information, then CRAs' opinions would not matter, and there would be no policy or regulatory concern regarding their activities, which is not the case.

${ }^{8}$ Livingston et al. (2008) investigate the links between split ratings and rating migrations, using a sample of corporate issuers rated by S\&P and Moody's over the period 1983 to 2001, while we address a related question for European sovereign issuers using more recent data (of crucial importance given the GFC). We also consider outlook and watch status, and include data from Fitch.
} 
CRAs form their opinions on sovereign creditworthiness based on a combination of both qualitative and quantitative considerations in accordance with proprietary methodologies (ESMA, 2013a). Some factors used by CRAs are similar, i.e. CRAs in common consider GDP per capita, governmental financial resources, political stability and debt structure (e.g. Mellios and Paget-Blanc, 2006), but they use some different qualitative and quantitative factors and attach different weights to these factors (e.g. IMF, 2010; Fabozzi and Vink, 2015). S\&P emphasises the probability of default, while Moody's uses an 'expected losses' approach, which accounts for default probability and loss given default assessments. Fitch considers probability of default and recovery given default. These factors can result in disagreements about the rating level and outlook/watch status of an issuer, leading to split ratings. These factors could also affect the manner in which CRAs adjust their ratings or review their outlook or watch status, and how equity markets react to credit signals from different CRAs.

\subsection{Recent $E U$ regulatory reforms affecting the rating industry}

CRAs have faced increased scrutiny during the GFC. Efforts have been made to enhance the performance, transparency and supervision of CRAs, and to reduce the reliance on ratings (IMF, 2010). In particular, the supervision of CRAs has been tightened. In December 2009, the EU instigated regulation for CRAs within the European jurisdiction, including registration procedures, governance requirements, internal controls, disclosure rules and improvements in rating methodologies. The phased EU regulation comprised CRA I Regulation in December 2010, CRA II Regulation in May 2011 and CRA III Regulation in November 2011. The European Securities and Markets Authority (ESMA) assumed responsibility for CRAs' regulation in Europe in July 2011. The European Commission is required to report to the Parliament by July 2016 to reassess the state of affairs. 
EU regulators are striving to reduce reliance on CRAs by removing/replacing the references to CRA ratings in regulations and collateral policies. However, ESMA (2015) has identified the elimination (or changing) of all rating-dependent regulation as impractical and now recommends mitigating the mechanistic reliance on ratings. Our third research question contributes to the policy agenda by investigating whether the recent EU regulation of CRAs has any effects on the CRAs' negative signals and their market impact.

\section{Data sample}

The sample consists of daily long-term foreign-currency sovereign ratings, watch status and outlook status which have been assigned by the largest three CRAs (Fitch, Moody's and S\&P) from July 2006 to November 2014 for 27 countries in the European Union (EU). ${ }^{9}$ The rating announcements are collated directly from CRAs' publications. We identify actual rating changes according to a mapped 20-notch numerical scale (AAA/Aaa = $20, \mathrm{AA}+/ \mathrm{Aa} 1=19, \mathrm{AA} / \mathrm{Aa} 2=18 \ldots \mathrm{CCC}-/ \mathrm{Caa} 3=2, \mathrm{CC} / \mathrm{Ca}, \mathrm{SD}-\mathrm{D} / \mathrm{C}=1)^{10}$, by notches on the basis of daily intervals. In addition, to identify credit signals we use a 58-point rating scale; this is a comprehensive credit rating (CCR) scale that incorporates both the actual ratings and credit outlook/watch status ${ }^{11}$, as follows: $\mathrm{AAA} / \mathrm{Aaa}=58, \mathrm{AA}+/ \mathrm{Aa} 1=55$, $\mathrm{AA} / \mathrm{Aa} 2=52 \ldots \mathrm{CCC}-/ \mathrm{Caa} 3=4, \mathrm{CC} / \mathrm{Ca}, \mathrm{SD}-\mathrm{D} / \mathrm{C}=1$, and we add ' +2 ' for positive watch, ' +1 ' for positive outlook, '-1' for negative outlook, '-2' for negative watch, and ' 0 ' for stable

\footnotetext{
${ }^{9}$ The start date is chosen as broadly consistent with Arezki et al. (2011). See the Appendix for the list of countries. Croatia joined the EU in July 2013, which is too late for this sample period.

${ }^{10}$ AAA/Aaa rated issuers have the highest quality and the lowest default risk, while issuers rated at SDD/C categories are in default. See Tichy (2011) for a fuller explanation of the alphabetical ratings.

${ }^{11}$ A complete CRA credit opinion on an issuer consists of a credit rating and a rating outlook/watch status. Several studies (e.g. Hill and Faff, 2010; Afonso et al., 2012) find that outlook and watch signals are at least as important as rating changes in their market impact. Using the $C C R$ scale, the same numerical score may represent different credit status. For example, issuers rated AAA with negative watch and AA+ with positive outlook carry the same numerical score ' 56 '. However, migrations between states with the same numerical score are extremely unlikely and there are no such cases in the data sample. Also, in the lowest numerical category, the only case of outlook/watch was when Greece was rated CC/Negative outlook by S\&P between 27 July 2011 and 27 February 2012, and we include this in numerical category ' 1 ' using the 58 -point rating scale.
} 
outlook and no watch/outlook assignments (Sy 2004). Negative (positive) outlook signals arise from (i) cases of changes to negative (positive) outlook from stable/positive (stable/negative) outlook, and (ii) cases of changes to stable outlook from positive (negative) outlook. Negative (positive) watch signals are recorded (i) in cases when a given sovereign is placed on review for possible downgrade (upgrade), and (ii) in cases when a sovereign rating is confirmed subsequent to a review for possible upgrade (downgrade).

There are 75,743 daily observations for each CRA. Figure 1 presents the distribution of daily numerical ratings. AAA/Aaa ratings represent $34 \%$ of the total number of daily observations. This is driven by some AAA/Aaa-rated sovereigns having no rating actions throughout the sample period (e.g. Denmark and Sweden). Speculative-grade ratings represent only $8.6 \%$ of the total. The average rating of the 27 EU countries by each CRA is '16' ('A+/A1') using the 20-notch scale. Using the 58-point scale, S\&P assigns a slightly lower average rating ('45’) than Moody’s and Fitch ('46’).

Rows 1-17 of Table 1 summarize the sovereign credit signals. The majority of the signals are negative (37 solo rating downgrades, 62 negative watch signals, 66 negative outlook actions, and 134 combined actions of rating downgrades and negative watch or outlook signals). In comparison, there are 165 positive signals. S\&P is the most active CRA with 191 credit events, whereas there are 136 and 137 events by Moody's and Fitch, respectively. This can be attributed to S\&P's greater emphasis on short-term accuracy (100 outlook signals and 45 watch actions). Moody's is more likely than other CRAs to adjust its sovereign ratings by multiple notches when the actions are taken (Row 15). Rows 18-26 of Table 1 summarize the credit actions using the 58-point scale, and a similar picture emerges. ${ }^{12}$

Figure 2 presents the distribution of signals using the 58-point scale. A weak positive trend continues until 2008-H1, followed by a dramatic increase in unfavourable news until

\footnotetext{
${ }^{12}$ Table 1 also presents the descriptive statistics for pre- and post-regulation sub-samples. The cut-off date is 1 July 2011 because ESMA assumed supervisory responsibility at this time (see Section 2.2).
} 
June 2013, especially in 2011-H2 and 2012-H1. The growing downgrade pressure arises from weakening public finances and growth, along with heightened concerns about excessive longterm government debt. The rating signals are spatially concentrated, whereby Cyprus, Greece, Italy, Ireland, Portugal and Spain are most prominent in downgrades. A weak positive trend is observed in 2013-H2 and 2014-H1, driven by the reported (yet weak) growth as a result of significant structural adjustment and institutional reform along with a related reduction in market stress (e.g. Moody's, 2013, Fitch, 2014; S\&P, 2014; ECB, 2015). A similar picture emerges on comparing the distribution of credit actions in the pre-regulation period from $1^{\text {st }}$ July 2006 to $30^{\text {th }}$ June 2011 , and the post-regulation period from $1^{\text {st }}$ of July 2011 to $30^{\text {th }}$ November 2014 (see Table 1$){ }^{13}$

Table 2 shows that rating disagreements are common across the CRAs, with 52.2\% (39.9\%) of daily observations in the case of S\&P and Moody's (Fitch) and 40.4\% between Moody's and Fitch, based on the 20-notch scale. Most rating differentials are one notch, however in some cases the split can reach up to 5 notches. Using the 58-point scale, there are inevitably higher percentages of rating differentials, whereby the highest frequency of splits is between S\&P and Moody's (63.1\%), versus 51.8\% (52.9\%) between Fitch and S\&P (Moody's). ${ }^{14}$ Moody's tends to be the most generous CRA during the pre-regulation period, assigning higher ratings than Fitch in $80.1 \%(80.0 \%)$ and S\&P in $89.0 \%(89.6 \%)$ of total split cases based on the 20-notch (58-point) scales. Moody's tends to be the harshest CRA in the post-regulation period, assigning lower ratings than Fitch in $77.1 \%(79.6 \%)$ and $\mathrm{S} \& \mathrm{P}$ in $56.5 \% \%(56.9 \%)$ of total split-rated cases, based on the 20-notch (58-point) scales. S\&P

\footnotetext{
${ }^{13}$ As a comparison, during the pre-GFC period of September 2000-June 2006, the sample of 27 EU sovereigns used in this paper had very stable ratings, with only 26 credit signals by Moody's, 42 by S\&P and 45 by Fitch. During that period, positive credit signals ( 25 by Moody's, 30 by S\&P and 35 by Fitch) hugely outnumbered negative signals ( 1 by Moody's, 12 by S\&P and 10 by Fitch). This was driven by economic growth, the accession of some countries to the $\mathrm{EU}$, and a benign macroeconomic environment. ${ }^{14}$ Almost all countries in the sample have experienced split ratings during the period July 2006-November 2014 using the 58-point rating scale, with the exceptions of Denmark and Sweden across the three CRAs, and Finland in the case of Moody's versus Fitch.
} 
appears to be harsher than Fitch, with S\&P assigning a lower rating than Fitch in around $80 \%$ of cases during the pre-regulation period and $66 \%$ of the cases in the post- regulation period.

The high percentages of disagreement between CRAs on their assessment of the creditworthiness of European countries are not surprising. In the GFC context, it is more difficult to determine the amounts and recoverability of vast potential losses to investors from holding sovereign debt. Investors holding Greek, Irish and Portuguese debt are potentially exposed to bailout agreements, which are dependent on successful implementation of austerity programmes. Moreover, the strong interdependence among EU countries complicates the assessment of cross-border debt holdings and potential spill-over effects. There are differences of opinion about EU countries' prospects for effective spending cuts, increased tax revenues/compliance, economic growth, support for banking systems, and the countries' financial and economic stability.

\section{Methodology}

For the analysis of split ratings, both directions (rating, outlook or watch status from a given CRA is higher or lower than that from the other CRA) and size of split rating are considered. Models for future downgrades and upgrades should be estimated separately due to their expected different behaviour (e.g. Fuertes and Kalotychou, 2007; Livingston et al., 2008). Because of limited upgrades within the sample (see Table 1$)^{15}$, we only estimate downgrade models, as follows:

$$
\begin{aligned}
D N_{i, t}^{*}{ }^{*}= & \beta_{1} 1 N-H-A_{i m}+\beta_{2} 2 N-H-A_{i m}+\beta_{3} 1 N-L-A_{i m}+\beta_{4} 2 N-L-A_{i m}+ \\
& +\beta_{5} H-\text { Watch }-A_{i m}+\beta_{6} L-\text { Watch }-A_{i m}+\beta_{7} H-\text { Outlook }-A_{i m}+ \\
& +\beta_{8} L-\text { Outlook }-A_{i m}+\gamma \text { Spec }_{i t}+\lambda \text { Growth }_{i y}+\psi \text { Co }_{i}+\zeta Y_{t}+\varepsilon_{i} ; \quad \varepsilon_{i} \sim N(0,1)
\end{aligned}
$$

\footnotetext{
${ }^{15}$ Positive credit signals are mainly concentrated in the 12-month period between July 2013 and June 2014 (see Figure 2). On estimating Eq. (1) and (2) with positive credit signals as the dependent variable, the results show mixed results, with either insignificant links between split ratings and positive credit actions or incorrect signs. Mixed results also appear in the post-regulation period (which has a relatively higher number of positive signals).
} 


$$
\begin{aligned}
D N_{i, t}{ }^{*} A & =\beta_{1} 1 N-H-B_{i m}+\beta_{2} 2 N-H-B_{i m}+\beta_{3} 1 N-L-B_{i m}+\beta_{4} 2 N-L-B_{i m}+ \\
& +\beta_{5} H-\text { Watch }-B_{i m}+\beta_{6} L-\text { Watch }-B_{i m}+\beta_{7} H-\text { Outlook }-B_{i m}+ \\
& +\beta_{8} L-\text { Outlook }-B_{i m}+\gamma \text { Spec }_{i t}+\lambda \text { Growth }_{i y}+\psi \text { Co }_{i}+\zeta Y_{t}+\varepsilon_{i} ; \varepsilon_{i} \sim N(0,1)
\end{aligned}
$$

$D N_{i, t}^{*}$ is an unobserved latent variable related to the observed ordinal rating changes $D N_{i, t}$ that equals 1, 2, 3, or 4, representing downgrades (by CRA $B$ in Eq. (1) and by CRA $A$ in Eq. (2)) by 1,2, 3 and $>3$ CCR points using the 58-point scale, or 0 otherwise. The link between $D N_{i, t}^{*}$ and $D N_{i, t}$ is:

$$
D N_{i, t}=\left[\begin{array}{l}
0 \text { (i.e. no rating change) if } D N_{i, t}^{*} \leq \mu_{1} \\
1 \text { (i.e. downgrade by } 1 \text { CCR) if } \mu_{1}<D N_{i, t}^{*} \leq \mu_{2} \\
2 \text { (i.e. downgrade by } 2 C C R \text { ) if } \mu_{2}<D N_{i, t}^{*} \leq \mu_{3} \\
3 \text { (i.e. downgrade by } 3 C C R \text { ) if } \mu_{3}<D N_{i, t}^{*} \leq \mu_{4} \\
4 \text { (i.e. downgrade by } 3 C C R \text { ) if } \mu_{4}<D N_{i, t}^{*}
\end{array}\right]
$$

Maximum likelihood is used to estimate the cut-off points $\mu_{z}$ (where $\mu_{1}<\mu_{2}<\mu_{3}<\mu_{4}$ ) and the $\beta, \lambda, \gamma, \psi$ and $\zeta$ coefficients.

$1 \mathrm{~N}-\mathrm{H}-\mathrm{A}_{\text {im }}\left(2 \mathrm{~N}-\mathrm{H}-\mathrm{A}_{\text {im }}\right)$ is a dummy variable taking the value of 1 if sovereign $i$ has one notch (> one-notch) higher rating from CRA $A$ than from CRA $B$ at 90 days ${ }^{16}(m)$ prior to the credit action at time $t, 0$ otherwise.

$1 N-L-A_{i m}\left(2 N-L-A_{i m}\right)$ is a dummy variable taking the value of 1 if sovereign $i$ has one notch (> one-notch) lower rating from CRA $A$ than from CRA $B$ at 90 days prior to the credit action at time $t, 0$ otherwise.

$H$-Watch- $A_{i m}\left(L-\right.$ Watch- $\left.A_{\text {im }}\right)$ is a dummy variable taking the value of 1 if sovereign $i$ has a watch status with a more (less) favourable/positive implication by CRA $A$ than that by CRA $B$ at 90 days prior to the credit action at time $t, 0$ otherwise.

16 The choice of the 90-day look-back time horizon (for $1 N-H-A_{i m}, 2 N-H-A_{i m}, 1 N-L-A_{i m}, 2 N-L-A_{i m}, H-$ Watch-A $A_{i m}, L$-Watch- $A_{i m}$ variables in Eq. 1 and Eq. 2) is consistent with Williams et al. (2013) and Alsakka et al. (2014). Further, the CRAs express an ex-ante target of 90 days to take action once an issuer is placed on a watch list (e.g. Williams et al., 2013). 
$H$-Outlook-A $A_{\text {im }}\left(L-O u t l o o k-A_{\text {im }}\right)$ is a dummy variable taking the value of 1 if sovereign $i$ has an outlook status with a more (less) favourable/positive implication by CRA $A$ than that by CRA $B$ at 90 days prior to the credit action at time $t, 0$ otherwise.

Spec $_{i t}$ is a control dummy taking the value of 1 if sovereign $i$ is rated at the speculative-grade category within the prior 90 days (by either CRA $A$ or $B$ ) before the rating change by the potential follower, and 0 otherwise. This variable is included to account for the influence of the current level of rating on subsequent credit actions.

Growth $_{i t}$ indicates the annual GDP growth rate (obtained from the World Bank) in country $i$ in the year of the rating change by the follower CRA. It controls for any effect of the business cycle in country $i$ on the probabilities of subsequent credit actions, and its inclusion is motivated by Bangia et al. (2002) and Livingston et al. (2008).

Co is a series of country dummy variables to control for any country-specific effects.

$Y$ is a series of year dummies, which are included to account for the time effect, i.e. potential variation in rating change patterns over the sampled years.

We calculate the marginal effects (MEs) to estimate the economic impact of the significant factors on the probabilities of rating changes. MEs estimate the change in the dependent variable that is caused by a 1 -unit change in an independent variable when the other independent variables are kept at their mean.

Following the investigation of rating transitions of split-rated European countries, we examine the information content of sovereign credit signals in the domestic stock markets. As above, we only investigate negative signals. The data on equity market indices are obtained from Bloomberg L.P. and the headline indices in each national stock market are used. ${ }^{17} \mathrm{We}$ estimate the models as follows:

$$
C A R_{i t}=\alpha+\beta \Delta C C R_{i t}+\gamma_{1} C C R_{i t}+\gamma_{2} \text { PRIOREVENTS }_{i t}+\gamma_{3} \operatorname{VIX}{ }_{t}+\psi C o_{i}+\zeta Y_{t}+\varepsilon_{i t}
$$

${ }^{17}$ The list of the national stock market indices along with the descriptive statistics are provided in the Appendix. 
$C A R_{i t}$ is the cumulative mean-adjusted abnormal return for days $t$ and $t+1$ of country $i$ subject to the credit event announced on day $t$ (see Hill and Faff, 2010). The mean return, which represents the expected daily return, is calculated using 120 trading days, from day $t-130$ to day $t-11$. The daily abnormal log return is derived by subtracting the expected log return from the realized log return on market indices. Abnormal log returns are accumulated over the two consecutive days to give cumulative abnormal returns. Using returns in a very short window $[t, t+1]$ avoids the contamination problem documented by Gande and Parsley (2005). Abnormal returns are denominated in USD in order to ensure that returns for different markets are comparable (e.g. Correa et al., 2014). Moreover, USD returns are the most relevant measure of stock performance from the perspective of international investors. ${ }^{18}$

$\triangle C C R_{i t}$ represents the credit signals variable; the downgrade by the CRA on an event date, measured in CCR points. For ease of interpretation, we take the absolute values of $\triangle C C R_{i t}$. $C C R_{i t}$ is the average of pre-event ratings assigned by the two CRAs to country $i$ on date $t-1$. It is considered as a control variable which summarizes the economic fundamentals, political and financial conditions of the sovereign $i$ when the credit event occurs.

PRIOREVENTS it is the cumulative CCR changes of country $i$ during the 14 days prior to day t. This captures the intensity of event clustering emphasized by Gande and Parsley (2005). $V I X_{t}$ controls for the effect of market volatility on the sensitivity of stock prices to adverse information. VIX $X_{t}$ is the log change of the CBOE Volatility index during the event window

\footnotetext{
${ }^{18}$ If returns are converted from the home currencies of the six countries outside the Euro-zone into Euros, these become foreign currency returns and subject to exchange rate fluctuations, whereas the returns for the 19 Euro-zone countries would remain local currency returns and unaffected by exchange rates. Due to this inconsistent treatment of returns as either in local or foreign currency when returns are measured in Euros, we convert returns for all countries into US Dollars as a common foreign currency. However, as a robustness test, we also estimate Eq. (3) and Eq. (4) using returns denominated in Euros, and qualitatively similar results are obtained. The tables are not reported in the interests of brevity but are available on request.
} 
(obtained from Datastream). We anticipate abnormal returns to be negative in response to negative signals and the reactions to be more pronounced when market volatility is high.

$C o$ and $Y$ are defined as in Eq. (1) and Eq. (2).

We use negative credit signals for split rated sovereigns only, i.e. 446 events which relate to 25 European countries (i.e. excluding Denmark and Sweden). On matching rating data with equity market data, the number of negative events is reduced from 446 to 416 (consisting of 211 events in the pre-regulation period and 205 events in the post-regulation period). Following Ferreira and Gama (2007), for each country in the sample, events are matched with an equal number of non-events collected randomly from all the non-event days available in the period. In order to ensure that returns on non-event days do not reflect a reaction to a rating signal, non-event days must be outside a 61-day event window (t-30, t+30). Hence, the intercept in Eq. (3) reflects the average abnormal returns for a non-event day and the slope coefficient $\beta$ measures the incremental returns on event days when CRAs announce a unit change in CCR.

For every event by a particular CRA, the pre-event rating affected by the announcement is either inferior (lower) or superior (higher) to the second rating assigned by another CRA which remains unchanged on the event date. To test the specific reactions of stock markets to credit signals for lower and higher ratings, $\triangle C C R_{i t}$ is interacted with two separate dummy variables namely $S U P_{i t}$ and $I N F_{i t} . S U P_{i t}$ takes the value of one if the CRA's rating subject to the announcement is superior (higher) compared with the other CRA, and zero otherwise. $I N F_{i t}$ takes the value of one if the CRA's rating subject to the announcement is inferior (lower) compared with the other CRA. The model is specified as follows:

$$
\begin{gathered}
C A R_{i t}=\alpha+\beta_{1} \Delta C C R_{i t} \times S U P_{i t}+\beta_{2} \Delta C C R_{i t} \times I N F_{i t}+\gamma_{1} C C R_{i t}+\gamma_{2} \text { PRIOREVENTS }_{i t}+ \\
\gamma_{3} V I X_{t}+\psi C o_{i}+\zeta Y_{t}+\varepsilon_{i t}
\end{gathered}
$$


Coefficients $\beta_{1}$ and $\beta_{2}$ measure the specific effects of a negative outlook signal (a change by one CCR point) for the superior ratings and inferior ratings, respectively. Vu et al. (2015) apply a similar specification to study global bond markets. To estimate the effect of a onenotch downgrade (three CCR points), $\beta_{1}$ and $\beta_{2}$ are multiplied by three. We anticipate that downgrading the inferior ratings leads to a more significant decrease in stock prices, hence we expect $\beta_{2}$ to be significant and larger than $\beta_{1} \cdot{ }^{19}$

We also examine the impact of split ratings on the cross-border effects of negative credit actions in Europe by each CRA. For each sovereign event in the home country $i$ (i.e. $\Delta C C R_{i t}$ ), we pool all the non-event countries $j$ and compute the abnormal returns of their stock market indices in the window $[t, t+1]$ (i.e. $C A R_{j t}$ ). We match each set of non-event country returns for a given event in the home country $i$ with randomly selected clean non-event-day observations for these non-event countries. We estimate the following equations:

$$
\begin{aligned}
C A R_{j t}= & \alpha+\beta \Delta C C R_{i t}+\gamma_{1} C C R_{i t}+\gamma_{2} C C R_{j t}+\gamma_{3} \text { PRIOREVENT } S_{i t}+ \\
& \gamma_{4} V I X_{t}+\psi C o_{i}+\eta C o_{j}+\zeta Y_{t}+\varepsilon_{i t} \\
C A R_{j t}= & \alpha+\beta_{1} \Delta C C R_{i t} \times S U P_{i t}+\beta_{2} \Delta C C R_{i t} \times I N F_{i t}+\gamma_{1} C C R_{i t}++\gamma_{2} C C R_{j t}+ \\
& \gamma_{3} \text { PRIOREVENTS }_{i t}+\gamma_{4} V I X_{t}+\psi C o_{i}++\eta C o_{j}+\zeta Y_{t}+\varepsilon_{i t}
\end{aligned} \forall j \notin i,
$$

Similar to Eq. (3) and (4), we include full sets of year and country dummies (event country and non-event country), prior events, log change of the CBOE Volatility index and the levels of event and non-event country comprehensive credit rating.

Finally, to investigate whether the recent EU regulation of CRAs reveals any effects on the CRAs' signals and their market impact, we estimate Eqs. (1) - (6) during two periods:

\footnotetext{
${ }^{19}$ Following Vu et al. (2015), we apply Yohai's (1987) MM-robust regression method using the full range of available observations to detect influential data points before estimating Eq. (3) and Eq. (4). Every observation whose standardized residual and/or robust distance lies far beyond the 'normal range' is an outlier and is hence deleted from the samples. The definition of normal range depends on the distributions of the standardized residuals and robust distance which vary across the samples. Nonetheless, in most cases, outliers are outside the range $[-5,+5]$ of robust standardized residuals and $[0,40]$ of the robust distance. The regressions are estimated as specified after outliers have been eliminated.
} 
pre-regulation ( $1^{\text {st }}$ July $2006-30^{\text {th }}$ June 2011$)$ and post-regulation $\left(1^{\text {st }}\right.$ July $2011-30^{\text {th }}$ November 2014). The cut-off date is selected to reflect the establishment of a new regulatory regime in July 2011, when ESMA assumed responsibility for CRAs' regulation in Europe.

\section{Empirical results}

\subsection{Relationship between split ratings and rating dynamics}

Table 3 presents the results of Eq. (1) and Eq. (2) for the full sample. Panel I considers the connection between S\&P-Moody's disagreements and Moody's negative actions. Sovereigns with either inferior S\&P outlook status or $>$ 1-notch lower S\&P rating have increased probabilities of Moody's downgrades by 1, 2, 3 and >3 CCR points of $0.04 \%$, $0.02 \%, 0.02 \%$ and $0.02 \%$, respectively. The MEs are economically significant given that the proportion of Moody's negative signals to the total number of daily observations is $0.12 \%$ (88/75743). Panel II considers the link between S\&P-Moody's disagreements and S\&P negative actions. S\&P is less likely to downgrade sovereigns with a higher Moody's rating, while disagreements on outlook status increase the probabilities of S\&P negative actions.

For S\&P-Fitch, Panel III shows that sovereigns with >1-notch lower S\&P rating or with inferior outlook or watch status by S\&P are more likely to experience negative actions by Fitch. Panel IV identifies that S\&P negative signals are only affected by disagreements with Fitch on outlook status. For Moody's-Fitch, Panels V and VI show that sovereigns with lower Moody's rating are more likely to experience negative actions by Fitch, while those with >1-notch lower rating or with inferior outlook status by Fitch are more likely to experience negative actions by Moody's.

Tables 4-6 present the results of Eq. (1) and (2) during the pre-regulation (Panels I and II) and post-regulation (Panels III and IV) periods. Table 4 considers S\&P-Moody's disagreements. Sovereigns with lower S\&P rating or with inferior S\&P outlook or watch status have much increased probabilities to experience negative actions by Moody's during 
the pre-regulation period only. Sovereigns with lower S\&P rating or with inferior S\&P outlook status are less likely to experience negative actions by S\&P. The latter is consistent across pre- and post-regulation periods, but the MEs are larger in the post-regulation era, implying a stronger (but still limited) connection between S\&P signals and any disagreement with Moody's.

Similar to Moody's case in Table 4, we find that Fitch's actions illustrate very limited linkages with S\&P post-regulation (Table 5). Sovereigns with lower S\&P rating or with inferior S\&P outlook or watch status are more likely to experience negative actions by Fitch during the pre-regulation period. In contrast, $\mathrm{S} \& \mathrm{P}$ negative signals are not influenced by split ratings with Fitch during the pre-regulation period. Table 6 reveals that negative signals by Fitch and Moody's also demonstrate very limited connection with their rating disagreements in the post-regulation period, while the pre-regulation period offers strong evidence of connections between these two CRAs.

To summarize, disagreements about ratings and outlook status (and to a lesser extent watch status) of European sovereigns are linked to subsequent CRA negative actions. In comparisons with Moody's or Fitch, S\&P's decisions on issuing negative signals are less strongly connected with their disagreements with the other CRAs. Notably, Moody's (Fitch) actions demonstrate very limited connection with S\&P and Fitch (Moody's) during the postregulation period. There is evidence of stronger (yet still limited) links between S\&P negative actions and its split ratings with Fitch and Moody's during the post-regulation period compared to pre-regulation.

\subsection{The impact of split ratings on stock markets' reactions to negative credit signals}

Estimation results for Eq. (3) and Eq. (4) are reported in Table 7. Section 5.1 highlights relatively weaker connections of split ratings between S\&P and Moody's/Fitch upon S\&P's negative rating actions. Therefore, we anticipate that S\&P's actions could contain more 
surprise content and therefore greater market impact. Panel I of Table 7 supports this. Stock price reactions to S\&P's negative actions are stronger on their inferior than superior ratings versus Moody's/Fitch, supporting our anticipation that such negative actions on inferior ratings are less predictable. The reported estimates are around $-0.46 \%$ for a negative outlook signal (i.e. $-1.38 \%$ for a one-notch downgrade (three-point CCR decrease)) on inferior S\&P ratings.

Section 5.1 shows that Moody's and Fitch signals are relatively more connected with disagreements with other CRAs. Moody's and Fitch signals are more predictable from the pre-event split ratings, thus we expect that their signals do not affect the markets as strongly as S\&P, and Table 7 supports this. In Panels II and III, the coefficients on credit signal variables and their interactions with pre-event split ratings are not statistically significant.

In summary, Table 7 adds important evidence to support our expectation about the market reactions to negative signals for split-rated European countries. Split ratings increase the likelihood that the higher ratings will be downgraded. S\&P's decisions to downgrade ratings which are already inferior to those assigned by other CRAs impart strong signals about weakening creditworthiness. This is in line with Vu et al. (2015) for global bond markets.

Table 8 presents the results for S\&P's negative credit signals during the pre- and postregulation periods. ${ }^{20,21}$ The market effect of S\&P's actions is concentrated in the preregulation period when S\&P's signals demonstrate very limited connections with its rating disagreements with the other CRAs (see Tables 4 and 5). In Panel I (II) of Table 8, abnormal returns on the domestic stock markets in the event window are estimated at $-0.47 \%(-0.39 \%)$ when S\&P announces a negative outlook signal in the pre-regulation period. For sovereigns

\footnotetext{
${ }^{20}$ Since there are insufficient events with superior ratings in the first estimation (the number of events is less than 10), we drop that variable.

${ }^{21}$ Equivalent estimations were completed for Moody's and Fitch negative signals. Consistent with Table 7, none of the coefficients of interest were significant. Hence, the tables are not reported in the interests of brevity but are available on request.
} 
rated lower by S\&P than Moody's, Panel I shows a coefficient of $-0.3 \%$ for a negative outlook signal. Section 5.1 highlights a stronger link between S\&P's signals and its disagreements with other CRAs in the post-regulation period. The insignificant coefficients in Table 8 for the post-regulation period are consistent with this. In summary, the sub-period analysis reveals evidence of a possible effect of the European CRA regulation on the stock market reactions to S\&P's signals.

\subsection{Spill-over effects}

Prior studies have reported that the market impact of rating signals extends beyond geographical borders (e.g. Arezki et al., 2011). We investigate the impact of split ratings on the cross-border effects of negative credit actions by the three CRAs, using Eq. (5) and Eq. (6), with the results presented in Table 9. We find significant stock market reactions in nonevent countries $j$ in the anticipated direction when S\&P announces a negative credit action on the event country $i$. The strong evidence in the case of S\&P is consistent with Section 5.2 on the 'own-market' effects. The pre-event split ratings influence the intensity of the spill-over effects in non-event countries. When S\&P rates lower than either Moody's or Fitch and downgrades a country, we find significant negative abnormal returns of $0.31 \%$ (when S\&P rates lower than Moody's) and $0.25 \%$ (when S\&P rates lower than Fitch), which are up to five times larger than the abnormal returns estimated for the negative outlook actions that occur when S\&P rates higher than either Moody’s or Fitch. ${ }^{22}$

We also examine the spill-over effects during the pre- and post-regulation periods. A similar picture emerges when we consider spill-over effects in the pre-regulation period compared with the results in Table 9. Interestingly, we observe much weaker and inconsistent

\footnotetext{
${ }^{22}$ Unexpectedly, a negative credit action by Moody's (Fitch) for a given event country induces a positive reaction in stock markets of its neighbour (non-event) countries in the region. However, the magnitude of the coefficients on the rating change variable $\triangle C C R_{i t}$ is small (below $0.1 \%$ ). Importantly, when split ratings are taken into account, Moody's (Fitch) negative actions induce negative responses in non-event countries, and this applies when Moody's (Fitch) assigns lower ratings than S\&P (Moody's).
} 
spill-over effects in the post-regulation period. For example, when S\&P announces a negative outlook signal, the non-event countries' abnormal returns are estimated at $-0.31 \%$ in the preregulation period, while the coefficient is insignificant in the post-regulation period. Also, S\&P negative outlook signals on sovereigns rated lower by S\&P than Fitch induce negative abnormal returns of $0.11 \%$ in the post-regulation period compared to $0.27 \%$ pre-regulation. This is consistent with Section 5.2. ${ }^{23}$

In summary, these findings show that negative signals by S\&P not only affect the own-country stock markets but also spill-over to other European countries' stock returns. Yet, the effect is weaker following the recent EU regulation of CRAs. Consistent with Section 5.2, there are stronger spill-over reactions when S\&P assigns a lower rating than the other CRAs prior to its downgrade action.

\section{Conclusions}

This paper examines credit actions by the largest three CRAs (Moody's, S\&P and Fitch) during the GFC. We investigate: (i) the impact of differences in ratings and outlook/watch status across CRAs on subsequent credit signals, (ii) the effect of split ratings on the stock market response to CRAs' sovereign credit events (both own-country and spillover effects), and (iii) the influence of the recently established European regulatory regime for CRAs in the context of (i) and (ii).

The dataset covers 27 EU sovereigns from July 2006 to November 2014, and we employ a 58-point scale to incorporate rating changes plus outlook and watch signals. We highlight that differences of rating opinion are very common in the sample, particularly when outlook and watch status are considered. Disagreements about sovereigns' creditworthiness have a significant effect on subsequent negative credit actions by each CRA. S\&P negative signals have the weakest links with its divergence in opinion about European sovereigns'

${ }^{23}$ The tables are not reported in the paper in the interests of brevity but are available on request. 
creditworthiness with the other two CRAs. The connections among the Moody's/Fitch actions and their disagreements with other CRAs tend to be stronger in the pre-regulation era.

European stock markets only react significantly to negative credit signals by S\&P, the CRA whose actions have least connection with those of other CRAs. Investor reactions are strongly influenced by split sovereign ratings between S\&P and Moody's. A one-notch downgrade by S\&P for a sovereign rated lower by S\&P than Moody's is associated with a negative abnormal return of $1.4 \%$, but similar actions for a sovereign rated higher by $\mathrm{S} \& \mathrm{P}$ than Moody's do not have a significant impact on stock returns. Pre-event rating differences between Moody's and S\&P/Fitch, and between Fitch and S\&P/Moody's do not affect the stock market reactions to Moody's nor Fitch negative signals. Negative signals by S\&P (but not other CRAs) also spill-over to other European countries' stock returns. Finally, stock markets' reactions to CRAs' negative signals in the post-regulation period are much weaker.

The objective of implementing the recent regulation of CRAs is to impose stricter rules on their operations, as well as encouraging rating users to develop stronger internal risk assessment methods. Since the introduction of ESMA oversight, CRAs' actions show less connection with each other, and stock market participants have become somewhat less responsive to CRAs' opinions. However, the EU regulatory regime for CRAs is still at an early stage and long-term evidence is needed to draw more concrete implications. 


\section{References}

Afonso, A., Furceri, D., Gomes, P., 2012. Sovereign credit ratings and financial markets linkages: Application to European data. Journal of International Money and Finance 31, no. 3: 606-638.

Alsakka, R., ap Gwilym, O., 2010. Leads and lags in sovereign credit ratings. Journal of Banking and Finance 34, no. 11: 2614-2626.

Alsakka, R., ap Gwilym, O., Vu, T.N., 2014. The sovereign-bank rating channel and rating agencies' downgrades during the European debt crisis. Journal of International Money and Finance 49, no. B: 235-257.

Alter, A., and Beyer, A., 2014. The dynamics of spillover effects during the European sovereign debt turmoil. Journal of Banking and Finance 42, 134-153.

Arezki, R., Candelon, B., Sy, A., 2011. Sovereign ratings news and financial markets spillovers: Evidence from the European debt crisis. IMF working paper, No. 11/68.

Bangia, A., Diebold, F.X., Kronimus, A., Schagen, C., and Schuermann, T., 2002. Ratings migration and the business cycle, with applications to portfolio stress testing. Journal of Banking and Finance 26, no. 2\&3: 445-474.

Becker, B., Milbourn, T., 2011. How did increased competition affect credit ratings?. Journal of Financial Economics 101, no. 3: 493-514.

Bongaerts, D., Cremers, M., Goetzmann, W., 2012. Tiebreaker: Certification and multiple credit ratings. Journal of Finance 67, no. 1: 113-152.

Borensztein, E., Cowan, K., Valenzuela, P., 2013. Sovereign ceiling lite? The impact of sovereign ratings on corporate ratings in emerging market economies. Journal of Banking and Finance 37, no. 11: 4014-4024.

Brooks, R., Faff, R., Hillier, D., Hillier, J., 2004. The national market impact of sovereign rating changes. Journal of Banking and Finance 28, no.1: 233-250.

Correa, R., Lee, K-H., Sapriza, H., Suarez, G.A., 2014. Sovereign credit risk, banks' government support and bank stock returns around the world. Journal of Money, Credit and Banking 46, no. 1: 93-121.

Deutsche Bundesbank, 2012. Annual Report 2011. March 2012.

ECB, 2015. European Central Bank Annual Report 2014. April 2015.

ESMA, 2013a. Credit Rating Agencies: Sovereign ratings investigation, ESMA/2013/1775. 
ESMA, 2013b. CRAs' market share calculation according to Article 8d of the CRA Regulation, ESMA/2013/1933.

ESMA, 2015. ESMA sees progress in reform of EU credit rating industry, Press release, ESMA/2015/1483, 2nd October 2015.

Fabozzi, F., Vink, D., 2015. The information content of three credit ratings: The case of European residential mortgage-backed securities. European Journal of Finance 21, no. 3: $172-194$.

Ferreira, M., Gama, P., 2007. Does sovereign debt ratings news spill over to international stock markets? Journal of Banking and Finance 31, no. 10: 3162-3182.

Fitch, 2012. Fitch Ratings Sovereign 2011 Transition and Default Study. March 2012.

Fitch, 2014. 2014 Mid-Year Sovereign Review and Outlook. July 2014.

Fuertes, A., Kalotychou, E., 2007. On sovereign credit migration: A study of alternative estimators and rating dynamics. Computational Statistics and Data Analysis 51, no. 7: 3448-3469.

Gande, A., Parsley, D., 2005. News spillovers in the sovereign debt market. Journal of Financial Economics 75, no. 3: 691-734.

Gennaioli, N., Martin, A., Rossi, S., 2014. Sovereign default, domestic banks, and financial institutions. Journal of Finance 69, no. 2: 819-866.

Harari, D., 2014. Causes of the eurozone crisis: A summary. House of Commons. Economic Policy and Statistics section, SN06831.

Hill, P., Faff, R., 2010. The market impact of relative agency activity in the sovereign ratings market. Journal of Business Finance and Accounting 37, no. 9\&10: 1309-1347.

IMF, 2010. Resolving the crisis legacy and meeting new challenges to financial stability. IMF Global Financial Stability Report: Meeting new challenges to stability and building a safer system, April.

Jorion, P., Liu, Z., Shi, C., 2005. Informational effects of regulation FD: Evidence from rating agencies. Journal of Financial Economics 76, no. 2: 309-330.

Livingston, M., Naranjo, A., Zhou, L., 2008. Split bond ratings and rating migration. Journal of Banking and Finance 32, no. 8: 1613-1624.

Livingston, M., Zhou, L., 2010. Split bond ratings and information opacity premiums. Financial Management 39, no. 2: 515-532. 
Livingston, M., Wei, D., Zhou, L., 2010. Moody's and S\&P ratings: Are they equivalent? Conservative ratings and split rated bond yields. Journal of Money, Credit and Banking 42, no. 7: 1267-1293.

Mellios, C., Paget-Blanc, E., 2006. Which factors determine sovereign credit ratings? European Journal of Finance 12, no. 4: 361-377.

Mongelli, F. P., 2008. European Economic and Monetary Integration, and the Optimum Currency Area Theory. European Central Bank. Economic Paper No. 302|Feb 2008.

Moody’s, 2011. Sovereign Default and Recovery Rates, 1983-2010. May 2011.

Moody’s, 2013. 2014 Outlook - Global Sovereigns: Credit Quality Stabilizing After Several Tumultuous Years. Moody’s Investors Service. November 2013.

Morgan, D., 2002. Rating banks: Risk and uncertainty in an opaque industry. American Economic Review 92, no. 4: 874-888.

Poon, W., Evans, D., 2013. Regulation Fair Disclosure's effect on the information content of bond rating changes. European Financial Management 19, no. 4: 775-800.

Powell, A., 2013. On sovereign ratings: observations and implications. BIS working paper No. 72 i.

S\&P, 2012. Standard \& Poor's takes various rating actions on 16 Eurozone sovereign governments. January 2012.

S\&P, 2014. Global Sovereign Rating Trends Mid-Year 2014. July 2014.

Sy, A., 2004. Rating the rating agencies: Anticipating currency crises or debt crises? Journal of Banking and Finance 28, no. 11: 2845-2867.

Tichy, G., 2011. Did Rating Agencies Boost the Financial Crisis? Intereconomics 46, 232 245.

Vu, H., Alsakka, R., ap Gwilym, O., 2015. The credit signals that matter most for sovereign bond spreads with split rating. Journal of International Money and Finance 53. pp. 174191.

Williams, G., Alsakka, R., ap Gwilym, O., 2013. The impact of sovereign rating actions on bank ratings in emerging markets. Journal of Banking and Finance 37, no. 2: 563-577.

Yohai, V.J., 1987. High breakdown-point and high efficiency robust estimates for regressions. The Annals of Statistics 15, no. 20: 642-656. 
Table 1- Descriptive statistics of the sovereign rating data sample

\begin{tabular}{|c|c|c|c|c|c|c|c|c|c|c|c|}
\hline & \multicolumn{4}{|c|}{ July 2006 - November 2014} & \multicolumn{3}{|c|}{ Pre-regulation } & \multicolumn{3}{|c|}{ Post-regulation } & \multirow[b]{2}{*}{ Row } \\
\hline & Moody's & S\&P & Fitch & Total & Moody's & $\mathbf{S \& P}$ & Fitch & Moody's & S\&P & Fitch & \\
\hline Solo rating downgrades & 8 & 16 & 13 & 37 & 6 & 5 & 7 & 2 & 11 & 6 & 1 \\
\hline Solo negative watch signals & 17 & 33 & 12 & 62 & 15 & 14 & 4 & 2 & 19 & 8 & 2 \\
\hline Solo negative outlook signals & 20 & 23 & 23 & 66 & 12 & 15 & 14 & 8 & 8 & 9 & 3 \\
\hline Combined events of rating downgrades and watch & 5 & 10 & 4 & 19 & 2 & 7 & 4 & 3 & 3 & 0 & 4 \\
\hline Combined events of rating downgrades and outlook & 38 & 40 & 37 & 115 & 16 & 22 & 18 & 22 & 18 & 19 & 5 \\
\hline Negative events & 88 & 122 & 89 & 299 & 51 & 63 & 47 & 37 & 59 & 42 & 6 \\
\hline Solo rating upgrades & 13 & 20 & 19 & 52 & 6 & 7 & 8 & 7 & 13 & 11 & 7 \\
\hline Solo positive watch signals & 4 & 1 & 2 & 7 & 3 & 0 & 2 & 1 & 1 & 0 & 8 \\
\hline Solo positive outlook signals & 23 & 33 & 22 & 78 & 9 & 15 & 12 & 14 & 18 & 10 & 9 \\
\hline Combined events of rating upgrades and watch/outlook & 5 & 4 & 2 & 11 & 1 & 0 & 1 & 4 & 4 & 1 & 10 \\
\hline Negative watch to negative outlook signal & 3 & 11 & 3 & 17 & 2 & 3 & 2 & 1 & 8 & 1 & 11 \\
\hline Positive events & 48 & 69 & 48 & 165 & 21 & 25 & 25 & 27 & 44 & 23 & 12 \\
\hline Total credit events (Rows 6 +12) & 136 & 191 & 137 & 464 & 72 & 88 & 72 & 64 & 103 & 65 & 13 \\
\hline All rating downgrades (Rows $1+4+5$ ) & 51 & 66 & 54 & 171 & 24 & 34 & 29 & 27 & 32 & 25 & 14 \\
\hline - of which by >1-notch (\% row 14$)$ & $49.0 \%$ & $28.8 \%$ & $35.2 \%$ & $36.8 \%$ & $41.7 \%$ & $20.6 \%$ & $27.6 \%$ & $55.6 \%$ & $37.5 \%$ & $44.0 \%$ & 15 \\
\hline All rating upgrades (Rows $7+10$ ) & 18 & 24 & 21 & 63 & 7 & 7 & 9 & 11 & 17 & 12 & 16 \\
\hline - of which by >1-notch (\% row 16$)$ & $16.7 \%$ & $25.0 \%$ & $14.3 \%$ & $19.0 \%$ & $0.0 \%$ & $0.0 \%$ & $11.1 \%$ & $27.3 \%$ & $35.3 \%$ & $16.7 \%$ & 17 \\
\hline 1-point negative action & 28 & 45 & 35 & 108 & 19 & 27 & 16 & 9 & 18 & 19 & 18 \\
\hline 2-point negative action & 18 & 36 & 12 & 66 & 15 & 15 & 8 & 3 & 21 & 4 & 19 \\
\hline 3 -point negative action & 18 & 21 & 23 & 62 & 9 & 13 & 14 & 9 & 8 & 9 & 20 \\
\hline$>3$-point negative action & 24 & 20 & 19 & 63 & 8 & 8 & 9 & 16 & 12 & 10 & 21 \\
\hline Negative actions using 58-point scale & 88 & 122 & 89 & 299 & 51 & 63 & 47 & 37 & 59 & 42 & 22 \\
\hline 1-point positive action & 34 & 44 & 25 & 103 & 17 & 18 & 15 & 17 & 26 & 10 & 23 \\
\hline 2-point positive action & 5 & 10 & 8 & 23 & 3 & 4 & 6 & 2 & 6 & 2 & 24 \\
\hline$>3$-point positive action & 9 & 15 & 15 & 39 & 1 & 3 & 4 & 8 & 12 & 11 & 25 \\
\hline Positive actions using 58-point scale & 48 & 69 & 48 & 165 & 21 & 25 & 25 & 27 & 44 & 23 & 26 \\
\hline
\end{tabular}

Positive actions using 58-point scale

48

This Table presents summary statistics for the dataset, which comprises three CRAs. The sample consists of daily long-term foreign-currency sovereign rating, outlook and 30 November 2014. 
Table 2- Agreement/disagreement on European sovereign ratings

\begin{tabular}{|c|c|c|c|c|c|c|c|c|c|}
\hline \multirow[b]{2}{*}{ Agencies } & \multicolumn{3}{|c|}{ July 2006 - November 2014} & \multicolumn{3}{|c|}{ Pre-Regulation } & \multicolumn{3}{|c|}{ Post-Regulation } \\
\hline & $\begin{array}{l}\text { S\&P and } \\
\text { Moody's }\end{array}$ & $\begin{array}{l}\text { S\&P and } \\
\text { Fitch }\end{array}$ & $\begin{array}{l}\text { Moody's } \\
\text { and Fitch }\end{array}$ & $\begin{array}{l}\text { S\&P and } \\
\text { Moody's }\end{array}$ & $\begin{array}{l}\text { S\&P and } \\
\text { Fitch }\end{array}$ & $\begin{array}{l}\text { Moody's } \\
\text { and Fitch }\end{array}$ & $\begin{array}{l}\text { S\&P and } \\
\text { Moody's }\end{array}$ & $\begin{array}{l}\text { S\&P and } \\
\text { Fitch }\end{array}$ & $\begin{array}{l}\text { Moody's } \\
\text { and Fitch }\end{array}$ \\
\hline \multicolumn{10}{|l|}{ Panel I-20-notch rating scale } \\
\hline Daily observations & 57743 & 57743 & 57743 & 33713 & 33713 & 33713 & 24030 & 24030 & 24030 \\
\hline Split $\%$ of whole sample & $52.2 \%$ & $39.9 \%$ & $40.4 \%$ & $48.7 \%$ & $32.8 \%$ & $36.5 \%$ & $56.9 \%$ & $49.9 \%$ & $45.9 \%$ \\
\hline Higher rating from first CRA; $\%$ of spilt & $31.7 \%$ & $27.3 \%$ & $53.0 \%$ & $11.0 \%$ & $19.2 \%$ & $80.1 \%$ & $56.5 \%$ & $34.8 \%$ & $22.9 \%$ \\
\hline 1-notch higher rating from first CRA & 6215 & 6001 & 10033 & 1170 & 1957 & 7550 & 5045 & 4044 & 2483 \\
\hline$>1$-notch higher rating from first CRA & 3319 & 297 & 2338 & 637 & 166 & 2300 & 2682 & 131 & 38 \\
\hline 1-notch lower rating from first CRA & 15149 & 14186 & 6559 & 9326 & 7967 & 2221 & 5823 & 6219 & 4338 \\
\hline$>1$-notch lower rating from first CRA & 5434 & 2583 & 4393 & 5302 & 977 & 232 & 132 & 1606 & 4161 \\
\hline \multicolumn{10}{|l|}{ Panel II - 58-point rating scale } \\
\hline Daily observations & 57743 & 57743 & 57743 & 33713 & 33713 & 33713 & 24030 & 24030 & 24030 \\
\hline Split $\%$ of whole sample & $63.1 \%$ & $51.8 \%$ & $52.9 \%$ & $56.2 \%$ & $42.8 \%$ & $45.3 \%$ & $72.8 \%$ & $64.5 \%$ & $63.6 \%$ \\
\hline Higher rating from first CRA; $\%$ of spilt & $32.7 \%$ & $27.0 \%$ & $50.2 \%$ & $10.4 \%$ & $19.8 \%$ & $80.0 \%$ & $56.9 \%$ & $33.8 \%$ & $20.4 \%$ \\
\hline 1-point higher rating from first CRA & 2652 & 2047 & 2710 & 371 & 833 & 2041 & 2281 & 1214 & 669 \\
\hline 2-point higher rating from first CRA & 1830 & 2230 & 1938 & 853 & 495 & 771 & 977 & 1735 & 1167 \\
\hline 3-point higher rating from first CRA & 3585 & 2646 & 6525 & 37 & 796 & 5306 & 3548 & 1850 & 1219 \\
\hline 4-point higher rating from first CRA & 500 & 969 & 1724 & 88 & 642 & 1694 & 412 & 327 & 30 \\
\hline 5-point higher rating from first CRA & 620 & 9 & 604 & 455 & 9 & 604 & 165 & 0 & 0 \\
\hline$>5$-point higher rating from first CRA & 2742 & 196 & 1830 & 177 & 91 & 1792 & 2565 & 105 & 38 \\
\hline 1-point lower rating from first CRA & 3745 & 4877 & 4428 & 2299 & 2623 & 764 & 1446 & 2254 & 3664 \\
\hline 2-point lower rating from first CRA & 2458 & 2245 & 1446 & 805 & 1166 & 996 & 1653 & 1079 & 450 \\
\hline 3-point lower rating from first CRA & 9980 & 10660 & 3765 & 6009 & 6124 & 895 & 3971 & 4536 & 2870 \\
\hline 4-point lower rating from first CRA & 2747 & 1333 & 1254 & 2399 & 595 & 248 & 348 & 738 & 1006 \\
\hline 5-point lower rating from first CRA & 858 & 483 & 329 & 800 & 414 & 0 & 58 & 69 & 329 \\
\hline$>5$-point lower rating from first CRA & 4743 & 2239 & 3984 & 4669 & 653 & 149 & 74 & 1586 & 3835 \\
\hline
\end{tabular}

This Table presents agreement/disagreement across three CRAs on 27 developed European sovereign ratings using the 20-notch rating scale in Panel I and the 58-point rating scale in Panel II. The pre-regulation period is from 1 July 2006 to 30 June 2011. The post-regulation period is from 1 July 2011 to 30 November 2014. 
Table 3 - Negative sovereign credit signals and split ratings during July 2006 - November 2014

\begin{tabular}{|c|c|c|c|c|c|c|c|c|c|c|c|c|c|}
\hline \multirow[t]{2}{*}{ Indep } & \multirow[t]{2}{*}{ Coef } & \multirow[t]{2}{*}{ t-value } & \multicolumn{4}{|c|}{ Marginal Effects (ME) \% } & \multirow[t]{2}{*}{ Indep } & \multirow[t]{2}{*}{ Coef } & \multirow[t]{2}{*}{ t-value } & \multicolumn{4}{|c|}{ Marginal Effects (ME) \% } \\
\hline & & & $\begin{array}{l}1 \\
(1 \mathrm{p} \mathrm{dw})\end{array}$ & $\begin{array}{l}2 \\
(2 p d w)\end{array}$ & $\begin{array}{l}3 \\
(3 p d w)\end{array}$ & 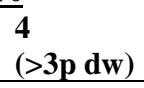 & & & & $\begin{array}{l}1 \\
(1 p d w)\end{array}$ & $\begin{array}{l}2 \\
(2 p d w)\end{array}$ & $\begin{array}{l}3 \\
(3 p d w)\end{array}$ & 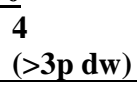 \\
\hline \multicolumn{14}{|c|}{ A. Negative credit actions and split ratings between Moody's and S\&P } \\
\hline \multicolumn{7}{|c|}{ Panel I- Moody's negative sovereign credit actions } & \multicolumn{7}{|c|}{ Panel II- S\&P negative sovereign credit actions } \\
\hline $1 \mathrm{~N}-\mathrm{H}-\mathrm{SP}$ & -0.174 & -0.97 & & & & & $1 \mathrm{~N}-\mathrm{H}-\mathrm{M}$ & $-0.309 * * *$ & -2.74 & -0.035 & -0.028 & -0.015 & -0.013 \\
\hline $2 \mathrm{~N}-\mathrm{H}-\mathrm{SP}$ & -0.060 & -0.32 & & & & & 2N-H-M & $-0.274 * *$ & -2.03 & -0.028 & -0.022 & -0.012 & -0.010 \\
\hline $1 \mathrm{~N}-\mathrm{L}-\mathrm{SP}$ & 0.020 & 0.18 & & & & & $1 \mathrm{~N}-\mathrm{L}-\mathrm{M}$ & -0.147 & -1.05 & & & & \\
\hline 2N-L-SP & $0.418 * * *$ & 3.37 & 0.038 & 0.024 & 0.023 & 0.025 & 2N-L-M & 0.186 & 1.23 & & & & \\
\hline H-Watch-SP & -0.218 & -1.38 & & & & & H-Watch-M & -0.081 & -0.52 & & & & \\
\hline L-Watch-SP & 0.278 & 1.61 & & & & & L-Watch-M & -0.075 & -0.46 & & & & \\
\hline H-Outlook-SP & -0.047 & 0.33 & & & & & H-Outlook-M & $0.276 * * *$ & 3.43 & 0.050 & 0.040 & 0.023 & 0.020 \\
\hline L-Outlook-SP & $0.433 * * *$ & 4.88 & 0.036 & 0.023 & 0.022 & 0.024 & L-Outlook-M & $0.223^{*}$ & 1.88 & 0.040 & 0.032 & 0.018 & 0.016 \\
\hline Spec & $-0.224 *$ & -1.68 & -0.009 & -0.005 & -0.005 & -0.005 & Spec & $-0.325 * *$ & -2.20 & -0.032 & -0.024 & -0.013 & -0.011 \\
\hline Growth & $-0.042 * * *$ & -2.88 & -0.002 & -0.001 & -0.001 & -0.002 & Growth & $-0.029 * * *$ & -2.57 & -0.004 & -0.003 & -0.002 & -0.002 \\
\hline Y\&CO Dum & Yes & & & & & & Y\&CO Dum & Yes & & & & & \\
\hline Pseudo $\mathrm{R}^{2}$ & $12.8 \%$ & & No. of ol & & 57,695 & & Pseudo $\mathrm{R}^{2}$ & $7.7 \%$ & & No. of obs & & 57,674 & \\
\hline
\end{tabular}

B. Negative credit actions and split ratings between $S \& P$ and Fitch

Panel III- Fitch negative sovereign credit actions

1N-H-SP $\quad-0.114$

2N-H-SP $\quad-0.012 \quad-0.03$

1N-L-SP $\quad 0.127 \quad 1.16$

2N-L-SP $\quad 0.399 * * * \quad 2.56$

H-Watch-SP $\quad 0.027 \quad 0.12$

L-Watch-SP $\quad 0.406^{* * *} \quad 2.90$

H-Outlook-SP $\quad 0.022 \quad 0.18$

L-Outlook-SP $\quad 0.258^{* * *} \quad 2.82$

$\begin{array}{lll}\text { Spec } & -0.180 & -1.27\end{array}$

Growth $\quad-0.007 \quad-0.50$

Y\&CO Dum Yes

Pseudo R ${ }^{2} \quad 9.8 \%$

No. of obs.

\section{Panel IV-S\&P negative sovereign credit actions}

$\begin{array}{lll}\text { 1N-H-F } & -0.119 & -1.29\end{array}$

2N-H-F $\quad-0.038 \quad-0.28$

1N-L-F $\quad 0.075 \quad 0.58$

2N-L-F $\quad 0.345 \quad 1.24$

H-Watch-F $\quad 0.022 \quad 0.15$

L-Watch-F $\quad 0.193 \quad 1.00$

$\begin{array}{lllllll}\text { H-Outlook-F } & 0.156^{*} & 1.84 & 0.027 & 0.022 & 0.012 & 0.011\end{array}$

$\begin{array}{lllllll}\text { L-Outlook-F } & 0.253^{* *} & 2.44 & 0.050 & 0.040 & 0.024 & 0.021\end{array}$

Spec $\quad-0.058 \quad-0.56$

$\begin{array}{lllllll}\text { Growth } & -0.021 * & -1.82 & -0.003 & -0.002 & -0.002 & -0.001\end{array}$

$\begin{array}{llll}\text { Y\&CO Dum } & \text { Yes } & \\ \text { Pseudo } R^{2} & 7.1 \% & \text { No. of obs. } & 57,674\end{array}$ 
Table 3. Continued

\begin{tabular}{|c|c|c|c|c|c|c|c|c|c|c|c|c|c|}
\hline \multirow[t]{2}{*}{ Indep } & \multirow[t]{2}{*}{ Coef } & \multirow[t]{2}{*}{ t-value } & \multicolumn{4}{|c|}{ Marginal Effects (ME) \% } & \multirow[t]{2}{*}{ Indep } & \multirow[t]{2}{*}{ Coef } & \multirow[t]{2}{*}{ t-value } & \multicolumn{4}{|c|}{ Marginal Effects (ME) \% } \\
\hline & & & $\begin{array}{c}1 \\
(1 p d w)\end{array}$ & $\begin{array}{c}2 \\
(2 p d w)\end{array}$ & $\begin{array}{c}3 \\
(3 p d w)\end{array}$ & $\begin{array}{c}4 \\
(>3 p ~ d w)\end{array}$ & & & & $\begin{array}{c}1 \\
(1 p d w)\end{array}$ & $\begin{array}{c}2 \\
(2 p d w)\end{array}$ & $\begin{array}{c}3 \\
(3 p \mathrm{dw})\end{array}$ & $-\begin{array}{c}4 \\
(>3 p d w)\end{array}$ \\
\hline \multicolumn{14}{|c|}{ C. Negative credit actions and split ratings between Fitch and Moody's } \\
\hline \multicolumn{7}{|c|}{ Panel V- Fitch negative sovereign credit actions } & \multicolumn{7}{|c|}{$\underline{\text { Panel VI- Moody's negative sovereign credit actions }}$} \\
\hline$\overline{1 \mathrm{~N}-\mathrm{H}-\mathrm{M}}$ & -0.111 & -0.89 & & & & & $\overline{1 \mathrm{~N}-\mathrm{H}-\mathrm{F}}$ & -0.034 & -0.21 & & & & \\
\hline $2 \mathrm{~N}-\mathrm{H}-\mathrm{M}$ & 0.099 & 0.59 & & & & & 2N-H-F & -0.229 & -1.32 & & & & \\
\hline $1 \mathrm{~N}-\mathrm{L}-\mathrm{M}$ & $0.224 *$ & 1.91 & 0.025 & 0.008 & 0.016 & 0.011 & $1 \mathrm{~N}-\mathrm{L}-\mathrm{F}$ & 0.106 & 0.93 & & & & \\
\hline $2 \mathrm{~N}-\mathrm{L}-\mathrm{M}$ & $0.315^{*}$ & 1.92 & 0.041 & 0.014 & 0.026 & 0.019 & 2N-L-F & $0.277^{*}$ & 1.84 & 0.023 & 0.014 & 0.014 & 0.015 \\
\hline H-Watch-M & 0.011 & 0.05 & & & & & H-Watch-F & -0.228 & -1.23 & & & & \\
\hline L-Watch-M & 0.145 & 0.88 & & & & & L-Watch-F & 0.260 & 1.15 & & & & \\
\hline H-Outlook-M & 0.146 & 1.43 & & & & & H-Outlook-F & -0.146 & -0.97 & & & & \\
\hline L-Outlook-M & 0.026 & 0.21 & & & & & L-Outlook-F & $0.406 * * *$ & 3.60 & 0.037 & 0.023 & 0.022 & 0.025 \\
\hline Spec & $-0.328 * *$ & -2.08 & -0.019 & -0.007 & -0.011 & -0.007 & Spec & $-0.263^{*}$ & -1.71 & -0.010 & -0.006 & -0.006 & -0.006 \\
\hline Growth & -0.005 & -0.37 & & & & & Growth & $-0.047 * * *$ & -2.84 & -0.002 & -0.002 & -0.001 & -0.002 \\
\hline Y\&CO Dum & Yes & & & & & & Y\&CO Dum & Yes & & & & & \\
\hline Pseudo $\mathrm{R}^{2}$ & $9.3 \%$ & & No. of obs. & & 57,695 & & Pseudo $\mathrm{R}^{2}$ & $11.7 \%$ & & No. of obs. & & 57,674 & 57,695 \\
\hline
\end{tabular}

This Table reports the results of ordered probit estimations of Eq. (1) and Eq. (2) using data for 27 European countries from Moody's and S\&P, S\&P and Fitch and Moody's and Fitch for 1 July 2006 to 30 November 2014. The dependent variables are: $D N_{i, t}^{M}, D N_{i, t}^{S P}, D N_{i, t}^{F}$, which equal 1, 2, 3, 4, representing downgrades by 1, 2, 3, >3 CCR points using the 58-point scale by Moody's, S\&P, Fitch respectively, or 0 otherwise. The independent variables are as follows. $1 N-H$-CRA (2N-H-CRA) is a dummy variable taking the value of 1 if a given sovereign has a one notch (>one-notch) higher rating from the given CRA at 90 days prior to the credit action at time $t, 0$ otherwise. $1 N-L$ $C R A(2 N-L-C R A)$ is a dummy variable taking the value of 1 if a given sovereign has one-notch (> one-notch) lower rating from the given CRA at 90 days prior to the credit action at time $t, 0$ otherwise. $H$-Watch-CRA (L-Watch-CRA) is a dummy variable taking the value of 1 if a given sovereign has watch status with a more (less) favourable/positive implication by the given CRA at 90 days prior to the credit action at time $t, 0$ otherwise. $H$-Outlook-CRA (L-Outlook-CRA) is a dummy variable taking the value of 1 if given sovereign has outlook status with a more (less) favourable/positive implication by the given CRA at 90 days prior to the credit action at time $t, 0$ otherwise. Spec is a dummy taking the value of 1 if a given sovereign is rated at the speculative-grade category within the prior 90 days (by at least one CRA) before the credit action by the potential follower CRA, 0 otherwise. Growth is the growth rate in a given country in the year of credit action. Full sets of year and country dummies are included. We apply Huber-White robust standard errors. We also estimate and report the impact of each variable on the probability of a rating change (marginal effect (ME)), but only for variables with significant (at $10 \%$ or lower) coefficients. ***Significant at $1 \%$ level; **significant at $5 \%$ level; * significant at $10 \%$ level. The estimates of the four threshold parameters are significant at the $1 \%$ level in all estimations, and are not shown here. 
Table 4 - Negative sovereign credit signals and split ratings between Moody's and S\&P - Subperiod analyses

\begin{tabular}{|c|c|c|c|c|c|c|c|}
\hline Indep & Coef & t-value & Ave ME \% & Indep & Coef & t-value & Ave ME \% \\
\hline \multirow{2}{*}{\multicolumn{4}{|c|}{$\begin{array}{l}\text { Panel I- Pre-regulation } \\
\text { Moody's negative sovereign credit actions }\end{array}$}} & \multirow{2}{*}{\multicolumn{4}{|c|}{$\begin{array}{l}\text { Panel II- Pre-regulation } \\
\text { S\&P negative sovereign credit actions }\end{array}$}} \\
\hline & & & & & & & \\
\hline \multirow[t]{2}{*}{$1 \& 2 \mathrm{~N}-\mathrm{H}-\mathrm{SP}$} & 0.100 & 0.24 & & $1 \mathrm{~N}-\mathrm{H}-\mathrm{M}$ & $-0.262 *$ & -1.70 & 0.015 \\
\hline & & & & $2 \mathrm{~N}-\mathrm{H}-\mathrm{M}$ & -0.210 & -1.01 & \\
\hline $1 \mathrm{~N}-\mathrm{L}-\mathrm{SP}$ & $0.240^{*}$ & 1.67 & 0.012 & $1 \& 2 \mathrm{~N}-\mathrm{L}-\mathrm{M}$ & 0.010 & 0.03 & \\
\hline 2N-L-SP & $0.803 * * *$ & 5.48 & 0.108 & & & & \\
\hline H-Watch-SP & $-0.464 * *$ & -2.33 & 0.010 & H-Watch-M & 0.141 & 0.50 & \\
\hline L-Watch-SP & $0.585^{* *}$ & 2.13 & 0.071 & L-Watch-M & -0.401 & -1.17 & \\
\hline H-Outlook-SP & -0.369 & -1.21 & & H-Outlook-M & $0.249 * *$ & 1.19 & 0.022 \\
\hline L-Outlook-SP & $0.543 * * *$ & 4.75 & 0.044 & L-Outlook-M & 0.135 & 0.68 & \\
\hline Spec & -0.089 & -0.56 & & Spec & -0.043 & -0.19 & \\
\hline Growth & $-0.046 * *$ & -2.42 & 0.002 & Growth & -0.017 & -1.27 & \\
\hline Y\&CO dummy & Yes & & & Y\&CO dummy & Yes & & \\
\hline Pseudo $\mathrm{R}^{2}$ & $16.0 \%$ & No. of obs. & 33,692 & Pseudo $\mathrm{R}^{2}$ & $10.3 \%$ & No. of obs. & 33,688 \\
\hline \multicolumn{4}{|c|}{ Panel III- Post-regulation } & \multicolumn{4}{|c|}{$\underline{\text { Panel IV- Post-regulation }}$} \\
\hline \multicolumn{4}{|c|}{ Moody's negative sovereign credit actions } & \multicolumn{4}{|c|}{$\underline{\text { S\&P negative sovereign credit actions }}$} \\
\hline $1 \mathrm{~N}-\mathrm{H}-\mathrm{SP}$ & -0.206 & -1.01 & & $1 \mathrm{~N}-\mathrm{H}-\mathrm{M}$ & $-0.427 * *$ & -2.21 & 0.042 \\
\hline 2N-H-SP & -0.406 & -1.57 & & 2N-H-M & $-0.607^{*}$ & -1.91 & 0.035 \\
\hline $1 \mathrm{~N}-\mathrm{L}-\mathrm{SP}$ & -0.233 & -1.47 & & $1 \mathrm{~N}-\mathrm{L}-\mathrm{M}$ & 0.068 & 0.44 & \\
\hline 2N-L-SP & 0.044 & 0.14 & & 2N-L-M & 0.060 & 0.28 & \\
\hline H-Watch-SP & 0.132 & 0.59 & & H-Watch-M & -0.285 & -1.30 & \\
\hline L-Watch-SP & 0.112 & 0.45 & & L-Watch-M & 0.104 & 0.48 & \\
\hline H-Outlook-SP & 0.147 & 1.06 & & H-Outlook-M & $0.277^{*}$ & 1.92 & 0.051 \\
\hline L-Outlook-SP & $0.252^{*}$ & 1.71 & 0.028 & L-Outlook-M & $0.263^{*}$ & 1.85 & 0.044 \\
\hline Spec & -0.061 & -0.25 & & Spec & 0.012 & 0.04 & \\
\hline Growth & -0.006 & -0.16 & & Growth & -0.009 & -0.27 & \\
\hline Y\&CO dummy & Yes & & & Y\&CO dummy & Yes & & \\
\hline Pseudo $\mathrm{R}^{2}$ & $10.2 \%$ & No. of obs. & 24,004 & Pseudo $\mathrm{R}^{2}$ & $10.2 \%$ & No. of obs. & 23,986 \\
\hline
\end{tabular}

This Table reports the results of ordered probit estimations of Eq. (1) and Eq. (2) using data for 27 European countries from Moody's and S\&P for the pre-regulation period (1 July 2006 to 30 June 2011) and for the postregulation period (1 July 2011 - 30 November 2014). The dependent variables are: $D N_{i, t}^{M} \quad\left(D N_{i, t}^{S P}\right)$ in Panels I and III (II and IV), which equal 1, 2, 3, 4, representing downgrades by 1, 2, 3, >3 CCR points using the 58-point scale by Moody's (S\&P), or 0 otherwise. For the definitions of the independent variables, see Table 3. If there are a very limited number of observations which are $>1$-notch higher (lower) from the given CRA (i.e. 2N-HCRA (2N-L-CRA)), we combine these observations into the variable '1N-H-CRA' ('1N-L-CRA'). In other words, ' $1 \& 2 \mathrm{~N}-\mathrm{H}-\mathrm{CRA}$ '(' $1 \& 2 \mathrm{~N}-\mathrm{L}-\mathrm{CRA}$ ') is a dummy variable taking the value of 1 if a given sovereign has 1 or $>1$ notch higher (lower) rating from the given CRA at 90 days prior to the credit action at time $t, 0$ otherwise. We apply Huber-White robust standard errors. We also estimate the impact of each variable on the probability of a rating change (marginal effect (ME)), but we only report the average ME (Ave ME) for variables with significant (at $10 \%$ or lower) coefficients. 'Ave ME' is the mean of the ME values for the four downgrade categories. The ME for each downgrade category (as presented in Table 3) is not reported in the interests of brevity, but is available on request. ***Significant at $1 \%$ level; **significant at $5 \%$ level; * significant at $10 \%$ level. The estimates of the four threshold parameters are significant at the $1 \%$ level in all estimations, and are not shown here. 
Table 5 - Negative sovereign credit signals and split ratings between S\&P and Fitch - Subperiod analyses

\begin{tabular}{|c|c|c|c|c|c|c|c|}
\hline Indep & Coef & t-value & Ave ME \% & Indep & Coef & t-value & Ave ME \% \\
\hline \multirow{2}{*}{\multicolumn{4}{|c|}{$\begin{array}{l}\text { Panel I- Pre-regulation } \\
\text { Fitch negative sovereign credit actions }\end{array}$}} & \multirow{2}{*}{\multicolumn{4}{|c|}{$\begin{array}{l}\text { Panel II- Pre-regulation } \\
\text { S\&P negative sovereign credit actions }\end{array}$}} \\
\hline & & & & & & & \\
\hline $1 \mathrm{~N}-\mathrm{H}-\mathrm{SP}$ & -0.210 & -0.77 & & $1 \mathrm{~N}-\mathrm{H}-\mathrm{F}$ & -0.047 & -0.37 & \\
\hline $2 \mathrm{~N}-\mathrm{H}-\mathrm{SP}$ & -0.158 & -0.39 & & $2 \mathrm{~N}-\mathrm{H}-\mathrm{F}$ & 0.019 & 0.07 & \\
\hline $1 \mathrm{~N}-\mathrm{L}-\mathrm{SP}$ & $0.510 * * *$ & 4.15 & 0.064 & $1 \mathrm{~N}-\mathrm{L}-\mathrm{F}$ & -0.040 & -0.18 & \\
\hline 2N-L-SP & $0.962 * * *$ & 4.13 & 0.036 & $2 \mathrm{~N}-\mathrm{L}-\mathrm{F}$ & 0.321 & 1.01 & \\
\hline H-Watch-SP & 0.393 & 1.31 & & H-Watch-F & 0.142 & 0.70 & \\
\hline L-Watch-SP & $0.737 * * *$ & 3.13 & 0.192 & L-Watch-F & 0.524 & 1.50 & \\
\hline H-Outlook-SP & -0.096 & -0.46 & & H-Outlook-F & 0.128 & 0.99 & \\
\hline L-Outlook-SP & $0.498 * * *$ & 3.94 & 0.075 & L-Outlook-F & 0.168 & 1.18 & \\
\hline Spec & -0.149 & -0.56 & & Spec & -0.215 & -0.95 & \\
\hline Growth & -0.015 & -0.90 & & Growth & -0.001 & -0.07 & \\
\hline Y\&CO dummy & Yes & & & Y\&CO dummy & Yes & & \\
\hline Pseudo $\mathrm{R}^{2}$ & $11.5 \%$ & No. of obs. & 33,688 & Pseudo $\mathrm{R}^{2}$ & $10.0 \%$ & No. of obs. & 33,688 \\
\hline \multicolumn{4}{|c|}{ Panel III- Post-regulation } & \multicolumn{4}{|c|}{ Panel IV- Post-regulation } \\
\hline \multicolumn{4}{|c|}{ Fitch negative sovereign credit actions } & \multicolumn{4}{|c|}{ S\&P negative sovereign credit actions } \\
\hline \multirow[t]{2}{*}{$1 \& 2 \mathrm{~N}-\mathrm{H}-\mathrm{SP}$} & -0.290 & -1.22 & & $1 \mathrm{~N}-\mathrm{H}-\mathrm{F}$ & $-0.252 *$ & -1.76 & 0.029 \\
\hline & & & & $2 \mathrm{~N}-\mathrm{H}-\mathrm{F}$ & -0.131 & -0.59 & \\
\hline $1 \mathrm{~N}-\mathrm{L}-\mathrm{SP}$ & 0.250 & 1.60 & & $1 \& 2 \mathrm{~N}-\mathrm{L}-\mathrm{F}$ & -0.058 & -0.35 & \\
\hline 2N-L-SP & 0.080 & 0.42 & & & & & \\
\hline H-Watch-SP & -0.278 & -0.97 & & H-Watch-F & -0.013 & -0.06 & \\
\hline L-Watch-SP & 0.091 & 0.39 & & L-Watch-F & 0.239 & 0.92 & \\
\hline H-Outlook-SP & 0.264 & 1.28 & & H-Outlook-F & 0.052 & 0.42 & \\
\hline L-Outlook-SP & $0.278^{* *}$ & 2.04 & 0.032 & L-Outlook-F & $0.310^{*}$ & 1.80 & 0.063 \\
\hline Spec & 0.219 & 1.18 & & Spec & 0.253 & 1.25 & \\
\hline Growth & -0.046 & 1.47 & & Growth & -0.019 & -0.60 & \\
\hline Y\&CO dummy & Yes & & & Y\&CO dummy & Yes & & \\
\hline Pseudo $\mathrm{R}^{2}$ & $10.6 \%$ & No. of obs. & 24,007 & Pseudo $\mathrm{R}^{2}$ & $9.7 \%$ & No. of obs. & 23,986 \\
\hline
\end{tabular}

This Table reports the results of ordered probit estimations of Eq. (1) and Eq. (2) using data for 27 European countries from S\&P and Fitch for the pre-regulation period (1 July 2006 to 30 June 2011) and for the postregulation period (1 July 2011 - 30 November 2014). The dependent variables are: $D N_{i, t}^{F}\left(D N_{i, t}^{S P}\right)$ in Panels I and III (II and IV), which equal 1, 2, 3, 4, representing downgrades by 1, 2, 3, >3 CCR points using the 58-point scale by Fitch (S\&P), or 0 otherwise. For the definitions of the independent variables, see Table 3 . If there are a very limited number of observations which are $>1$-notch higher (lower) from the given CRA (i.e. 2N-H-CRA (2N-L-CRA)), we combine these observations into the variable '1N-H-CRA' ('1N-L-CRA'). In other words, ' $1 \& 2 \mathrm{~N}-\mathrm{H}-\mathrm{CRA}$ '(' $1 \& 2 \mathrm{~N}-\mathrm{L}-\mathrm{CRA}$ ') is a dummy variable taking the value of 1 if a given sovereign has 1 or $>1$ notch higher (lower) rating from the given CRA at 90 days prior to the credit action at time $t, 0$ otherwise.We apply Huber-White robust standard errors. We also estimate the impact of each variable on the probability of a rating change (marginal effect (ME)), but we only report the average ME (Ave ME) for variables with significant (at $10 \%$ or lower) coefficients. The ME for each downgrade category is not reported in the interests of brevity, but is available on request. ***Significant at $1 \%$ level; **significant at $5 \%$ level; * significant at $10 \%$ level. The estimates of the four threshold parameters are significant at the $1 \%$ level in all estimations, and are not shown here. 
Table 6 - Negative sovereign credit signals and split ratings between Fitch and Moody's - Subperiod analyses

\begin{tabular}{|c|c|c|c|c|c|c|c|}
\hline Indep & Coef & t-value & Ave ME \% & Indep & Coef & t-value & Ave ME \% \\
\hline \multirow{2}{*}{\multicolumn{4}{|c|}{$\begin{array}{l}\text { Panel I- Pre-regulation } \\
\text { Fitch negative sovereign credit actions }\end{array}$}} & \multirow{2}{*}{\multicolumn{4}{|c|}{$\begin{array}{l}\text { Panel II- Pre-regulation } \\
\text { Moody's negative sovereign credit actions }\end{array}$}} \\
\hline & & & & & & & \\
\hline $1 \mathrm{~N}-\mathrm{H}-\mathrm{M}$ & 0.190 & 0.95 & & \multirow[t]{2}{*}{$1 \& 2 \mathrm{~N}-\mathrm{H}-\mathrm{F}$} & \multirow[t]{2}{*}{-0.080} & \multirow[t]{2}{*}{-0.29} & \\
\hline $2 \mathrm{~N}-\mathrm{H}-\mathrm{M}$ & 0.451 & 1.10 & & & & & \\
\hline $1 \mathrm{~N}-\mathrm{L}-\mathrm{M}$ & 0.029 & 0.15 & & $1 \mathrm{~N}-\mathrm{L}-\mathrm{F}$ & $0.359 * *$ & 2.18 & 0.027 \\
\hline 2N-L-M & $0.469 *$ & 1.88 & \multirow[t]{2}{*}{0.079} & 2N-L-F & $0.405^{* *}$ & 1.79 & 0.039 \\
\hline H-Watch-M & -0.347 & -1.33 & & H-Watch-F & $-0.443^{*}$ & -1.91 & 0.012 \\
\hline L-Watch-M & $0.472 *$ & 1.79 & \multirow[t]{2}{*}{0.090} & L-Watch-F & 0.114 & 0.25 & \\
\hline H-Outlook-M & -0.144 & -0.55 & & H-Outlook-F & 0.052 & 0.20 & \\
\hline L-Outlook-M & $0.345^{* * *}$ & 3.05 & \multirow[t]{4}{*}{0.042} & L-Outlook-F & $0.556 * * *$ & 4.11 & 0.057 \\
\hline Spec & 0.013 & 0.05 & & Spec & $-0.352 *$ & -1.73 & 0.011 \\
\hline Growth & 0.004 & 0.22 & & Growth & $-0.065 * * *$ & -3.06 & 0.003 \\
\hline Y\&CO dummy & Yes & & & Y\&CO dummy & Yes & & \\
\hline Pseudo $\mathrm{R}^{2}$ & $9.8 \%$ & No. of obs. & 33,688 & Pseudo $\mathrm{R}^{2}$ & $13.7 \%$ & No. of obs. & 33,692 \\
\hline \multicolumn{4}{|c|}{ Panel III- Post-regulation } & \multicolumn{4}{|c|}{ Panel IV-Post-regulation } \\
\hline \multicolumn{4}{|c|}{ Fitch negative sovereign credit actions } & \multicolumn{4}{|c|}{ Moody's negative sovereign credit actions } \\
\hline \multirow[t]{2}{*}{$1 \& 2 \mathrm{~N}-\mathrm{H}-\mathrm{M}$} & -0.526 & -1.53 & & $1 \mathrm{~N}-\mathrm{H}-\mathrm{F}$ & -0.318 & -1.45 & \\
\hline & & & & $2 \mathrm{~N}-\mathrm{H}-\mathrm{F}$ & -0.411 & -1.52 & \\
\hline $1 \mathrm{~N}-\mathrm{L}-\mathrm{M}$ & -0.128 & -0.57 & & $1 \mathrm{~N}-\mathrm{L}-\mathrm{F}$ & $-0.633 * *$ & -2.19 & 0.016 \\
\hline 2N-L-M & 0.140 & 0.71 & & $2 \mathrm{~N}-\mathrm{L}-\mathrm{F}$ & -0.222 & -0.54 & \\
\hline H-Watch-M & -0.360 & -1.34 & & H-Watch-F & 0.364 & 0.88 & \\
\hline L-Watch-M & $0.582 *$ & 1.78 & 0.103 & L-Watch-F & 0.311 & 1.09 & \\
\hline H-Outlook-M & -0.439 & -1.34 & & H-Outlook-F & -0.241 & -1.16 & \\
\hline L-Outlook-M & 0.178 & 1.11 & & L-Outlook-F & -0.340 & -0.89 & \\
\hline Spec & -0.125 & -0.56 & & Spec & -0.019 & -0.07 & \\
\hline Growth & $0.087 * *$ & 2.51 & 0.006 & Growth & 0.008 & 0.24 & \\
\hline Y\&CO dummy & Yes & & & Y\&CO dummy & Yes & & \\
\hline Pseudo $\mathrm{R}^{2}$ & $12.8 \%$ & No. of obs. & 24,007 & Pseudo $\mathrm{R}^{2}$ & $13.3 \%$ & No. of obs. & 24,003 \\
\hline
\end{tabular}

This Table reports the results of ordered probit estimations of Eq. (1) and Eq. (2) using data for 27 European countries from Fitch and Moody's for the pre-regulation period (1 July 2006 to 30 June 2011) and for the postregulation period (1 July 2011 - 30 November 2014). The dependent variables are: $D N_{i, t}^{F}\left(D N_{i, t}^{M}\right)$ in Panels I and III (II and IV), which equal 1, 2, 3, 4, representing downgrades by 1, 2, 3, >3 CCR points using the 58-point scale by Fitch (Moody's), or 0 otherwise. For the definitions of the independent variables, see Table 3. If there are a very limited number of observations which are $>1$-notch higher (lower) from the given CRA (i.e. $2 \mathrm{~N}$-HCRA (2N-L-CRA)), we combine these observations into the variable '1N-H-CRA' ('1N-L-CRA'). In other words, ' $1 \& 2 \mathrm{~N}-\mathrm{H}-\mathrm{CRA}$ '(' $1 \& 2 \mathrm{~N}-\mathrm{L}-\mathrm{CRA}$ ') is a dummy variable taking the value of 1 if a given sovereign has 1 or $>1$ notch higher (lower) rating from the given CRA at 90 days prior to the credit action at time $t, 0$ otherwise.We apply Huber-White robust standard errors. We also estimate the impact of each variable on the probability of a rating change (marginal effect (ME)), but we only report the average ME (Avr ME) for variables with significant (at 10\% or lower) coefficients. The ME for each downgrade category is not reported in the interests of brevity, but is available on request. ***Significant at $1 \%$ level; **significant at $5 \%$ level; *significant at $10 \%$ level. The estimates of the four threshold parameters are significant at the $1 \%$ level in all estimations, and are not shown here. 
Table 7. The impact of split ratings on stock markets' reactions to negative credit signals in European countries during July 2006 - November 2014

\begin{tabular}{|c|c|c|c|c|c|c|c|c|c|c|c|c|}
\hline & \multicolumn{4}{|c|}{ Panel I - S\&P's negative signals } & \multicolumn{4}{|c|}{ Panel II - Moody's negative signals } & \multicolumn{4}{|c|}{ Panel III - Fitch's negative signals } \\
\hline & \multicolumn{2}{|c|}{ S\&P vs. Moody's } & \multicolumn{2}{|c|}{ S\&P vs. Fitch } & \multicolumn{2}{|c|}{ S\&P vs. Moody's } & \multicolumn{2}{|c|}{ Moody's vs. Fitch } & \multicolumn{2}{|c|}{ S\&P vs. Fitch } & \multicolumn{2}{|c|}{ Moody's vs. Fitch } \\
\hline & (i) & (ii) & (i) & (ii) & (i) & (ii) & (i) & (ii) & (i) & (ii) & (i) & (ii) \\
\hline$\Delta \mathrm{CCR}$ & $\begin{array}{l}-0.0025^{*} \\
(-1.83)\end{array}$ & & $\begin{array}{l}-0.0042 * * * \\
(-3.22)\end{array}$ & & $\begin{array}{l}-0.0013 \\
(-1.09)\end{array}$ & & $\begin{array}{l}-0.0005 \\
(-0.26)\end{array}$ & & $\begin{array}{l}0.0010 \\
(0.56)\end{array}$ & & $\begin{array}{l}0.0009 \\
(0.56)\end{array}$ & \\
\hline$\Delta \mathrm{CCR} * \mathrm{SUP}$ & & $\begin{array}{l}0.0001 \\
(0.07)\end{array}$ & & $\begin{array}{l}-0.0040 * * \\
(-2.49)\end{array}$ & & $\begin{array}{l}-0.0012 \\
(-0.92)\end{array}$ & & $\begin{array}{l}0.0002 \\
(0.07)\end{array}$ & & $\begin{array}{l}0.0012 \\
(0.65)\end{array}$ & & $\begin{array}{l}0.0013 \\
(0.82)\end{array}$ \\
\hline$\Delta \mathrm{CCR} * \mathrm{INF}$ & & $\begin{array}{l}-0.0047 * * * \\
(-2.72)\end{array}$ & & $\begin{array}{l}-0.0045^{* * * *} \\
(-2.80)\end{array}$ & & $\begin{array}{l}-0.0021 \\
(-0.93)\end{array}$ & & $\begin{array}{l}-0.0027 \\
(-1.25)\end{array}$ & & $\begin{array}{l}-0.0054 \\
(-1.12)\end{array}$ & & $\begin{array}{l}-0.0002 \\
(-0.05)\end{array}$ \\
\hline CCR & $\begin{array}{l}-0.0007 * * \\
(-2.07)\end{array}$ & $\begin{array}{l}-0.0004 \\
(-1.34)\end{array}$ & $\begin{array}{l}-0.0008^{* *} \\
(-2.04)\end{array}$ & $\begin{array}{l}-0.0008^{* * *} \\
(-2.03)\end{array}$ & $\begin{array}{l}-0.0006 \\
(-1.40)\end{array}$ & $\begin{array}{l}-0.0007 \\
(-1.40)\end{array}$ & $\begin{array}{l}0.0001 \\
(0.12)\end{array}$ & $\begin{array}{l}0.0001 \\
(0.15)\end{array}$ & $\begin{array}{l}0.0003 \\
(0.63)\end{array}$ & $\begin{array}{l}0.0002 \\
(0.48)\end{array}$ & $\begin{array}{l}0.0005 \\
(1.21)\end{array}$ & $\begin{array}{l}0.0006 \\
(1.29)\end{array}$ \\
\hline Prior Events & $\begin{array}{l}-0.0020 \\
(-0.92)\end{array}$ & $\begin{array}{l}-0.0019 \\
(-1.00)\end{array}$ & $\begin{array}{l}0.0004 \\
(0.75)\end{array}$ & $\begin{array}{l}0.0004 \\
(0.76)\end{array}$ & $\begin{array}{l}-0.0003 \\
(-0.32)\end{array}$ & $\begin{array}{l}-0.0003 \\
(-0.26)\end{array}$ & $\begin{array}{l}-0.0004 \\
(-0.17)\end{array}$ & $\begin{array}{l}0.0001 \\
(0.05)\end{array}$ & $\begin{array}{l}0.0009 \\
(0.37)\end{array}$ & $\begin{array}{l}0.0011 \\
(0.42)\end{array}$ & $\begin{array}{l}0.0016 \\
(0.86)\end{array}$ & $\begin{array}{l}0.0014 \\
(0.66)\end{array}$ \\
\hline VIX & $\begin{array}{l}-0.127 * * * \\
(-2.96)\end{array}$ & $\begin{array}{l}-0.121 * * * \\
(-2.87)\end{array}$ & $\begin{array}{l}-0.130 * * * \\
(-4.52)\end{array}$ & $\begin{array}{l}-0.131 * * * \\
(-4.51)\end{array}$ & $\begin{array}{l}-0.134 * * * \\
(-3.69)\end{array}$ & $\begin{array}{l}-0.135^{* * * *} \\
(-3.70)\end{array}$ & $\begin{array}{l}-0.111^{* *} \\
(-2.56)\end{array}$ & $\begin{array}{l}-0.105 * * \\
(-2.52)\end{array}$ & $\begin{array}{l}-0.152 * * * \\
(-4.14)\end{array}$ & $\begin{array}{l}-0.157 * * * \\
(-4.19)\end{array}$ & $\begin{array}{l}-0.123 * * * \\
(-2.92)\end{array}$ & $\begin{array}{l}-0.127 * * * \\
(-2.85)\end{array}$ \\
\hline Cons & $\begin{array}{l}0.0428^{*} \\
(1.81)\end{array}$ & $\begin{array}{l}0.0318 \\
(1.37)\end{array}$ & $\begin{array}{l}0.0549 * \\
(1.95)\end{array}$ & $\begin{array}{l}0.0561 * \\
(1.93)\end{array}$ & $\begin{array}{l}0.0589 \\
(1.56)\end{array}$ & $\begin{array}{l}0.0589 \\
(1.55)\end{array}$ & $\begin{array}{l}-0.0267 \\
(-0.89)\end{array}$ & $\begin{array}{l}-0.0277 \\
(-0.93)\end{array}$ & $\begin{array}{l}-0.0607 \\
(-1.63)\end{array}$ & $\begin{array}{l}-0.0588 \\
(-1.60)\end{array}$ & $\begin{array}{l}-0.0424 \\
(-1.20)\end{array}$ & $\begin{array}{l}-0.0439 \\
(-1.27)\end{array}$ \\
\hline Y \& CO dummy & yes & yes & yes & yes & yes & yes & yes & yes & yes & yes & yes & Yes \\
\hline No of observations & 180 & 180 & 148 & 148 & 158 & 158 & 128 & 128 & 154 & 154 & 146 & 146 \\
\hline Adjusted R-squared & $7.2 \%$ & $8.5 \%$ & $16.1 \%$ & $15.4 \%$ & $19.4 \%$ & $18.8 \%$ & $0.3 \%$ & $0.3 \%$ & $4.2 \%$ & $4.0 \%$ & $6.8 \%$ & $6.2 \%$ \\
\hline
\end{tabular}

This Table reports the results of Eq. (3) and Eq. (4) using data for 25 European countries rated unequally by S\&P, Moody's and Fitch during the period from 1 July 2006 to 30 November 2014. "S\&P vs. Moody’s", "S\&P vs. Fitch", and "Moody’s vs. Fitch" indicate that the samples of interest contain credit signals for sovereigns rated jointly and unequally by the respective pair of CRAs. The dependent variable is $C A R$ which measures the mean adjusted abnormal return in the window [ $t, t+1]$ for the national stock index of the event country on day $t$. "SUP" and "INF" are the dummies of superior and inferior ratings assigned by the CRA announcing the credit signal compared with one of the other two CRAs on day $t-1$. CCR is the average rating on the 58-point rating scale assigned to the sovereigns affected by the credit actions on day t-1. Prior Events measures the cumulative rating changes by all the three CRAs during the 14 days prior to the event days. VIX is the log change in the CBOE Volatility Index calculated for the window $[t, t+1]$. Full sets of year and country dummies are included. The model is estimated with Huber-White robust standard errors. t-values are in parenthesis. ***, **, and * refer to significant coefficients at $1 \%, 5 \%$ and $10 \%$ levels. 
Table 8 - The impact of split ratings on stock markets' reactions to negative credit signals by S\&P in European countries - Sub-period analyses

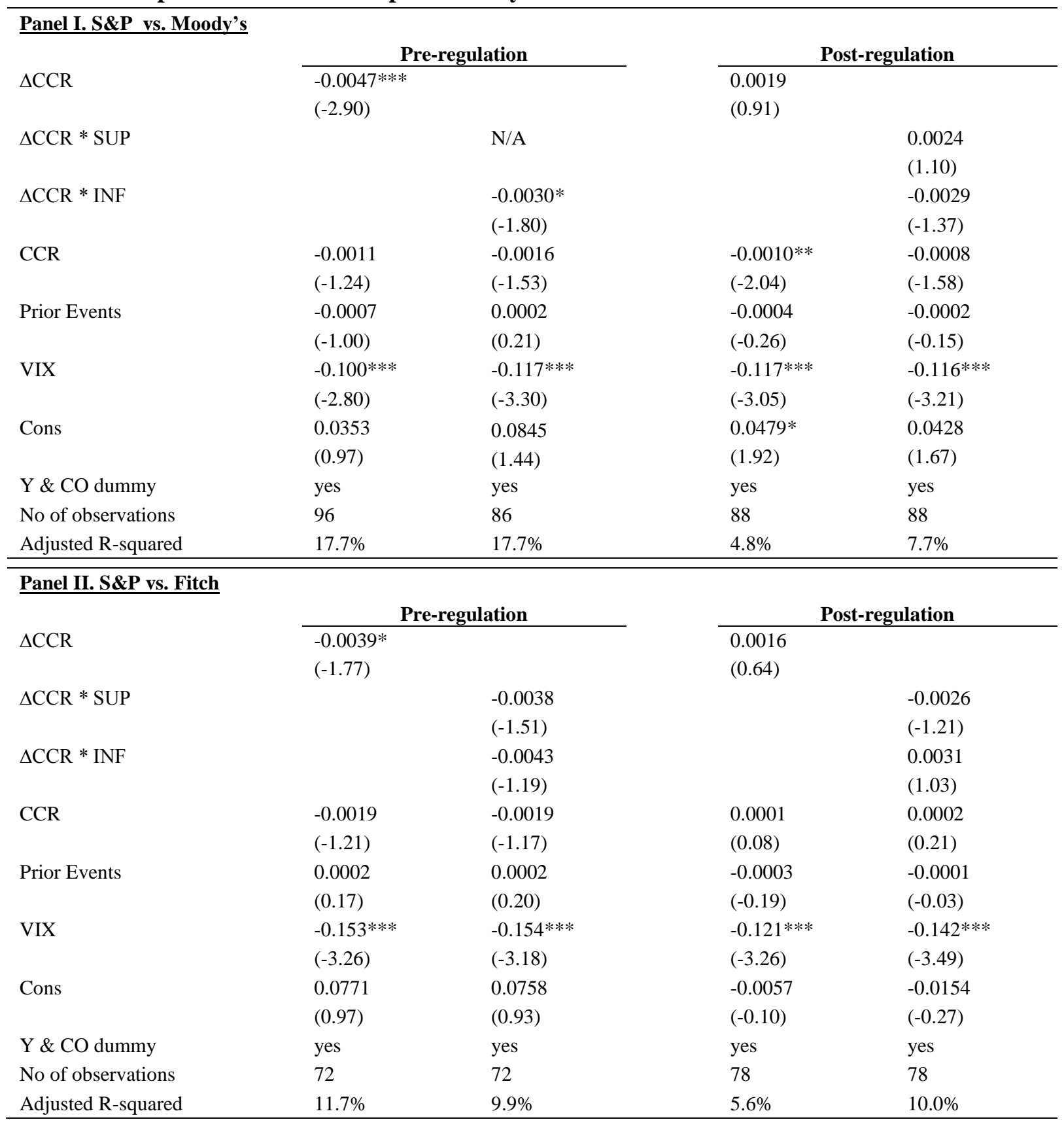

This Table reports the results of Eq. (3) and Eq. (4) using data on S\&P's negative credit signals for 25 European countries in the pre-regulation period (1 July 2006 to 30 June 2011) and the post-regulation period (1 July 2011 - 30 November 2014). "S\&P vs. Moody's" and "S\&P vs. Fitch" indicate that the samples of interest contain credit signals for sovereigns also rated (unequally) by Moody's and Fitch, respectively. The dependent variable is $C A R$ which measures the mean adjusted abnormal return in the window $[t, t+1]$ for the national stock index of the event country on day $t$. "SUP" and "INF" are the dummies of superior and inferior ratings assigned by S\&P compared with either Moody's or Fitch. Other variables are defined in the notes of Table 7. Full sets of year and country dummies are included. The model is estimated with Huber-White robust standard errors. t-values are in parenthesis. $* * *, * *$, and $*$ refer to significant coefficients at $1 \%, 5 \%$ and $10 \%$ levels. 
Table 9 - The impact of split ratings on non-event stock markets' reactions to negative credit signals in European event countries during Jul 2006 - Nov 2014

\begin{tabular}{|c|c|c|c|c|c|c|c|c|c|c|c|c|}
\hline & \multicolumn{4}{|c|}{ Panel I - S\&P's negative signals } & \multicolumn{4}{|c|}{ Panel II - Moody's negative signals } & \multicolumn{4}{|c|}{ Panel III - Fitch's negative signals } \\
\hline & \multicolumn{2}{|c|}{ S\&P vs. Moody's } & \multicolumn{2}{|c|}{ S\&P vs. Fitch } & \multicolumn{2}{|c|}{ S\&P vs. Moody's } & \multicolumn{2}{|c|}{ Moody's vs. Fitch } & \multicolumn{2}{|c|}{ S\&P vs. Fitch } & \multicolumn{2}{|c|}{ Moody's vs. Fitch } \\
\hline & (i) & (ii) & (i) & (ii) & (i) & (ii) & (i) & (ii) & (i) & (ii) & (i) & (ii) \\
\hline$\Delta \mathrm{CCR}$ & $\begin{array}{l}-0.0019 * * * \\
(-7.41)\end{array}$ & & $\begin{array}{l}-0.0020 * * * \\
(-7.38)\end{array}$ & & $\begin{array}{l}0.0005^{* * * *} \\
(2.74)\end{array}$ & & $\begin{array}{l}0.0009^{* *} \\
(4.59)\end{array}$ & & $\begin{array}{l}0.0005^{*} \\
(1.93)\end{array}$ & & $\begin{array}{l}-0.0006^{* *} \\
(-2.28)\end{array}$ & \\
\hline$\Delta \mathrm{CCR} * \mathrm{SUP}$ & & $\begin{array}{l}-0.0006^{* *} \\
(-2.07)\end{array}$ & & $\begin{array}{l}-0.0015^{* * *} \\
(-3.99)\end{array}$ & & $\begin{array}{l}0.0010^{* * * *} \\
(5.06)\end{array}$ & & $\begin{array}{l}0.0012^{* *} \\
(5.37)\end{array}$ & & $\begin{array}{l}0.0004 * \\
(1.76)\end{array}$ & & $\begin{array}{l}-0.0002 \\
(-0.82)\end{array}$ \\
\hline$\Delta \mathrm{CCR} * \mathrm{INF}$ & & $\begin{array}{l}-0.0031^{* * *} \\
(-7.89)\end{array}$ & & $\begin{array}{l}-0.0025 * * * \\
(-7.74)\end{array}$ & & $\begin{array}{l}-0.0023 * * * \\
(-7.19)\end{array}$ & & $\begin{array}{l}-0.0001 \\
(-0.40)\end{array}$ & & $\begin{array}{l}0.0016 \\
(1.41)\end{array}$ & & $\begin{array}{l}-0.0016^{* * *} \\
(-3.13)\end{array}$ \\
\hline $\mathrm{CCRi}$ & $\begin{array}{l}-0.0001 * * \\
(-2.27)\end{array}$ & $\begin{array}{l}0.0000 \\
(0.01)\end{array}$ & $\begin{array}{l}-0.0001 \\
(-1.27)\end{array}$ & $\begin{array}{l}-0.0001 \\
(-1.52)\end{array}$ & $\begin{array}{l}-0.0003 * * * \\
(-3.73)\end{array}$ & $\begin{array}{l}-0.0003 * * * \\
(-3.95)\end{array}$ & $\begin{array}{l}-0.0001 \\
(-0.65)\end{array}$ & $\begin{array}{l}-0.0000 \\
(-0.33)\end{array}$ & $\begin{array}{l}-0.0002 * * \\
(-1.97)\end{array}$ & $\begin{array}{l}-0.0002 * \\
(-1.78)\end{array}$ & $\begin{array}{l}-0.0001 \\
(-1.24)\end{array}$ & $\begin{array}{l}-0.0001 \\
(-1.03)\end{array}$ \\
\hline $\mathrm{CCRj}$ & $\begin{array}{l}-0.0002 * * \\
(-2.53)\end{array}$ & $\begin{array}{l}-0.0002 * * \\
(-2.20)\end{array}$ & $\begin{array}{l}-0.0003 * * \\
(-2.45)\end{array}$ & $\begin{array}{l}-0.0003 * * \\
(-2.46)\end{array}$ & $\begin{array}{l}-0.0001 \\
(-0.85)\end{array}$ & $\begin{array}{l}-0.0001 \\
(-1.14)\end{array}$ & $\begin{array}{l}-0.0001 \\
(-0.90)\end{array}$ & $\begin{array}{l}-0.0001 \\
(-1.01)\end{array}$ & $\begin{array}{l}0.0001 \\
(0.86)\end{array}$ & $\begin{array}{l}0.0001 \\
(0.88)\end{array}$ & $\begin{array}{l}-0.0001 \\
(-1.32)\end{array}$ & $\begin{array}{l}-0.0001 \\
(-1.14)\end{array}$ \\
\hline Prior Events & $\begin{array}{l}-0.0000 \\
(-0.16)\end{array}$ & $\begin{array}{l}-0.0000 \\
(-0.27)\end{array}$ & $\begin{array}{l}-0.0004^{* *} \\
(-2.31)\end{array}$ & $\begin{array}{l}-0.0005^{* *} \\
(-2.42)\end{array}$ & $\begin{array}{l}-0.0000 \\
(-0.21)\end{array}$ & $\begin{array}{l}0.0002 \\
(0.80)\end{array}$ & $\begin{array}{l}-0.0001 \\
(-0.72)\end{array}$ & $\begin{array}{l}0.0000 \\
(0.02)\end{array}$ & $\begin{array}{l}0.0007 * * \\
(2.46)\end{array}$ & $\begin{array}{l}0.0006^{* *} \\
(2.31)\end{array}$ & $\begin{array}{l}0.0003 \\
(1.32)\end{array}$ & $\begin{array}{l}0.0001 \\
(0.39)\end{array}$ \\
\hline VIX & $\begin{array}{l}-0.073 * * * \\
(-11.70)\end{array}$ & $\begin{array}{l}-0.071 * * * \\
(-11.24)\end{array}$ & $\begin{array}{l}-0.078 * * * \\
(-11.52)\end{array}$ & $\begin{array}{l}-0.079 * * * \\
(-11.66)\end{array}$ & $\begin{array}{l}-0.063^{* * *} \\
(-9.59)\end{array}$ & $\begin{array}{l}-0.064 * * * \\
(-9.90)\end{array}$ & $\begin{array}{l}-0.050^{* * *} \\
(-6.71)\end{array}$ & $\begin{array}{l}-0.046^{* * *} \\
(-6.18)\end{array}$ & $\begin{array}{l}-0.053^{* * *} \\
(-7.05)\end{array}$ & $\begin{array}{l}-0.052 * * * \\
(-6.94)\end{array}$ & $\begin{array}{l}-0.069 * * * \\
(-7.76)\end{array}$ & $\begin{array}{l}-0.072 * * * \\
(-7.93)\end{array}$ \\
\hline Constant & $\begin{array}{l}0.0128 * \\
(1.87)\end{array}$ & $\begin{array}{l}0.0050 \\
(0.72)\end{array}$ & $\begin{array}{l}0.0106 \\
(1.09)\end{array}$ & $\begin{array}{l}0.0125 \\
(1.29)\end{array}$ & $\begin{array}{l}0.0275^{* * *} \\
(3.12)\end{array}$ & $\begin{array}{l}0.0289 * * * \\
(3.28)\end{array}$ & $\begin{array}{l}0.0059 \\
(0.63)\end{array}$ & $\begin{array}{l}0.0042 \\
(0.45)\end{array}$ & $\begin{array}{l}0.0063 \\
(0.70)\end{array}$ & $\begin{array}{l}0.0057 \\
(0.63)\end{array}$ & $\begin{array}{l}0.0221 * * \\
(2.66)\end{array}$ & $\begin{array}{l}0.0200 * * \\
(2.43)\end{array}$ \\
\hline Year dummy & yes & yes & yes & yes & Yes & yes & yes & yes & yes & yes & yes & yes \\
\hline $\begin{array}{l}\text { Event \& non-event Country } \\
\text { dummies }\end{array}$ & yes & yes & yes & yes & Yes & yes & yes & yes & yes & yes & yes & yes \\
\hline No of observations & 4518 & 4518 & 3736 & 3736 & 3900 & 3900 & 3308 & 3308 & 3616 & 3616 & 3414 & 3414 \\
\hline No of negative signals & 92 & 92 & 75 & 75 & 79 & 79 & 66 & 66 & 77 & 77 & 73 & 73 \\
\hline Adjusted R-squared & $9.9 \%$ & $10.4 \%$ & $11.8 \%$ & $11.9 \%$ & $13.7 \%$ & $15 \%$ & $11.7 \%$ & $11.9 \%$ & $7.5 \%$ & $7.5 \%$ & $8.7 \%$ & $8.8 \%$ \\
\hline
\end{tabular}

This Table reports the results of Eq. (5) and Eq. (6) using data for 25 European countries rated unequally by S\&P, Moody's and Fitch during the period from 1 July 2006 to 30 November 2014. "S\&P vs. Moody's", "S\&P vs. Fitch", and "Moody's vs. Fitch" indicate that the samples of interest contain credit signals for sovereigns rated jointly and unequally by the respective pair of CRAs. The dependent variable is $C A R$ which measures the mean adjusted abnormal return in the window [ $t, t+1]$ for the national stock index of foreign country $j$ on day $t$ when a credit signal occurs in the event country $i$. "SUP" and "INF" are the dummies of superior and inferior ratings assigned to country $i$ by the CRA announcing the credit signal compared with one of the other two CRAs on day $t-1$. CCRi and CCRj are the average rating on the 58-point rating scale on day $t$ - 1 of the event country $i$ affected by the credit actions and the foreign non-event country $j$ respectively. Prior Events measures the cumulative rating changes of event country $i$ by all three CRAs during the 14 days prior to the event days. VIX is the log change in the CBOE Volatility Index calculated for the window $[t, t+1]$. Full sets of year dummy variables, event country and foreign country dummy variables are included. The model is estimated with Huber-White robust standard errors. t-values are in parenthesis. ***,**, and $*$ refer to significant coefficients at $1 \%, 5 \%$ and $10 \%$ levels. 

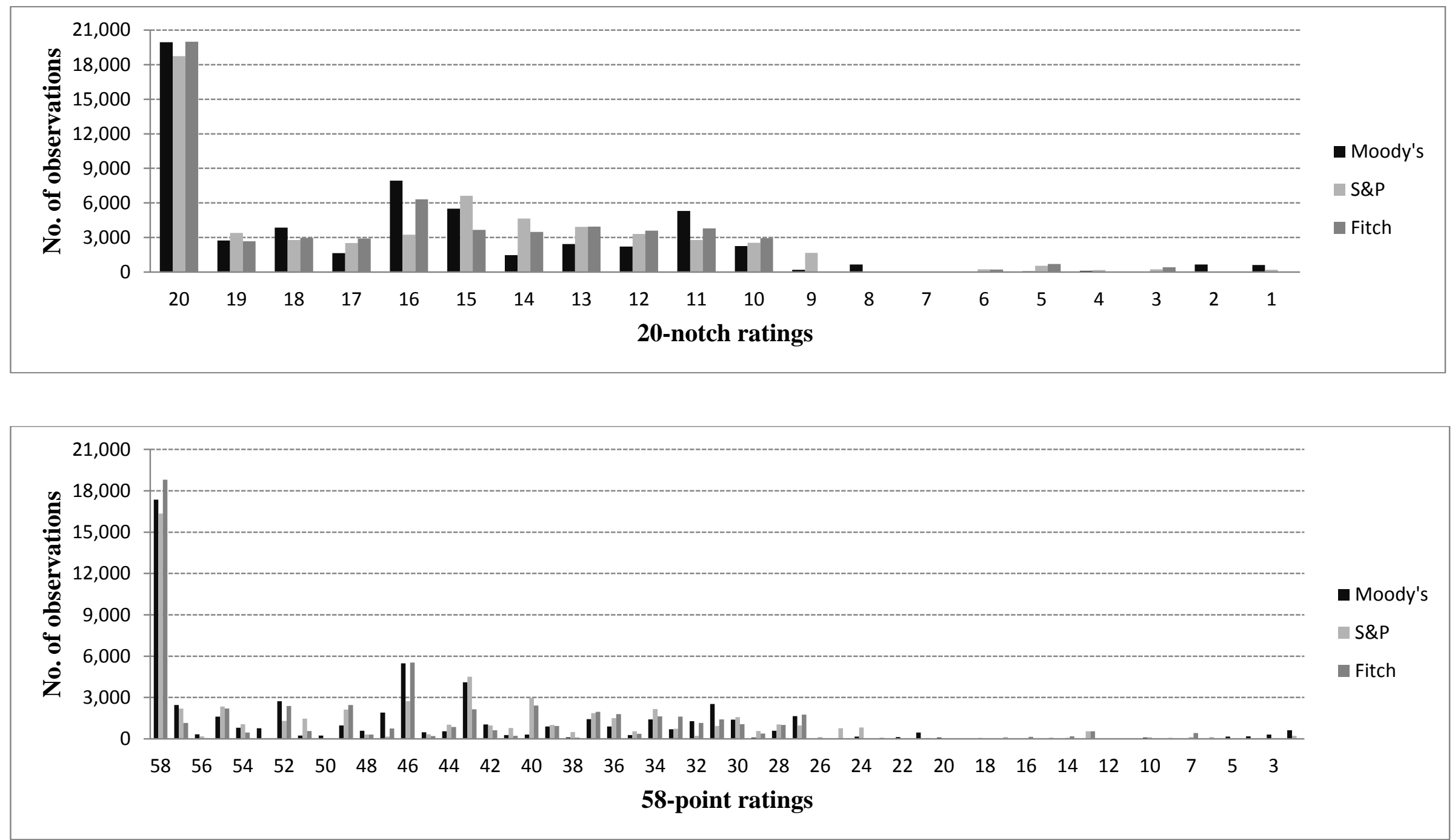

Figure 1: Distribution of daily sovereign ratings of 27 European countries from July 2006 to November 2014 based on 20-notch and 58-point rating scales. 


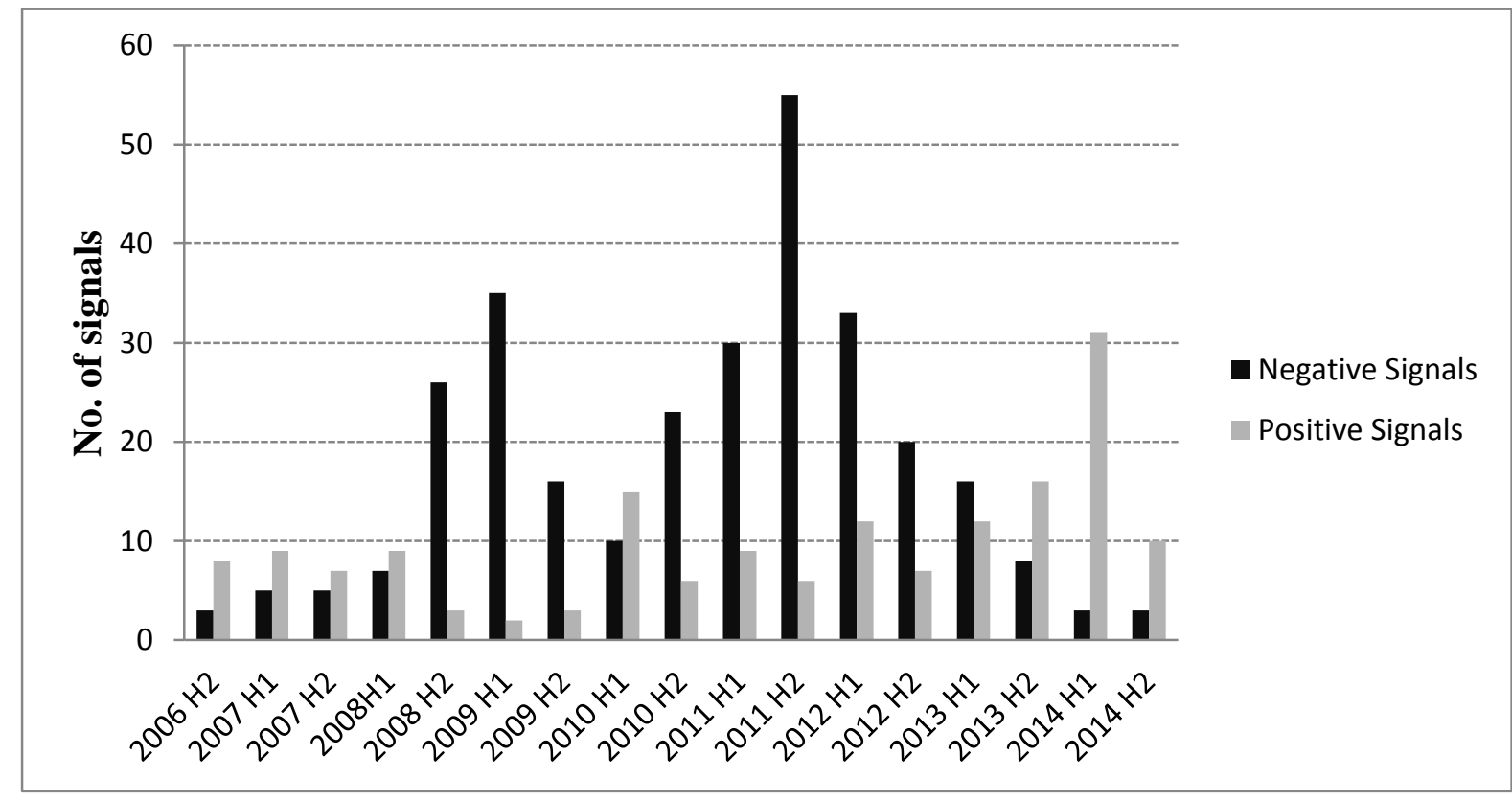

Figure 2: Distribution of negative and positive signals (including actual rating changes and outlook and watch signals) by the largest three CRAs for 27 European countries from July 2006 to November 2014 based on 58point rating scale. 


\section{Appendix}

List of national stock market indices

\begin{tabular}{|c|c|c|c|c|c|c|}
\hline Country & Index & Index name & Mean & S.D. & Min & Max \\
\hline Austria & ATX & AUSTRIAN TRADED ATX INDX & 0.0054 & 0.0123 & -0.0094 & 0.0176 \\
\hline Belgium & BEL20 & BEL 20 INDEX & -0.0044 & 0.0255 & -0.0495 & 0.0498 \\
\hline Bulgaria & SOFIX & SOFIX INDEX & -0.0068 & 0.0433 & -0.1003 & 0.1216 \\
\hline Cyprus & CYSMMAPA & GENERAL MARKET INDEX CSE & -0.0050 & 0.0458 & -0.1100 & 0.1219 \\
\hline Czech Republic & PX & PRAGUE STOCK EXCH INDEX & 0.0077 & 0.0454 & -0.0230 & 0.0751 \\
\hline Estonia & TALSE I & OMX TALLINN OMXT & -0.0017 & 0.0302 & -0.0924 & 0.0551 \\
\hline Finland & HEX & OMX HELSINKI INDEX & -0.0072 & 0.0151 & -0.0179 & 0.0035 \\
\hline France & $\mathrm{CAC}$ & CAC 40 INDEX & -0.0022 & 0.0176 & -0.0315 & 0.0395 \\
\hline Germany & DAX & DAX INDEX & -0.0307 & 0.0220 & -0.0462 & -0.0151 \\
\hline Greece & ASE & ATHEX COMPOSITE SHARE PR & -0.0082 & 0.0386 & -0.1084 & 0.0903 \\
\hline Hungary & BUX & BUDAPEST STOCK EXCH INDX & -0.0080 & 0.0281 & -0.0686 & 0.0714 \\
\hline Ireland & ISEQ & IRISH OVERALL INDEX & -0.0002 & 0.0253 & -0.0535 & 0.0596 \\
\hline Italy & FTSEMIB & FTSE MIB INDEX & 0.0056 & 0.0365 & -0.0692 & 0.1040 \\
\hline Latvia & RIGSE & OMX RIGA OMXR & -0.0004 & 0.0282 & -0.0760 & 0.0478 \\
\hline Lithuania & VILSE & OMX VILNIUS OMXV & -0.0067 & 0.0339 & -0.1350 & 0.0455 \\
\hline Luxembourg & LUXXX & LUXEMBOURG LUXX INDEX & -0.0070 & 0.0354 & -0.0320 & 0.0181 \\
\hline Malta & MALTEX & MALTA STOCK EXCHANGE IND & 0.0048 & 0.0145 & -0.0170 & 0.0389 \\
\hline Netherlands & AEX & AEX-INDEX & -0.0164 & 0.0167 & -0.0343 & 0.0056 \\
\hline Poland & WIG20 & WIG 20 & -0.0033 & 0.0578 & -0.0712 & 0.0690 \\
\hline Portugal & PSI20 & PSI 20 INDEX & -0.0078 & 0.0286 & -0.0941 & 0.0524 \\
\hline Romania & BET & BUCHAREST BET INDEX & 0.0033 & 0.0360 & -0.0507 & 0.0639 \\
\hline Slovakia & SKSM & SLOVAK SHARE INDEX & 0.0108 & 0.0404 & -0.0153 & 0.1093 \\
\hline Slovenia & SBITOP & SLOVENIAN BLUE CHIP IDX & 0.0039 & 0.0172 & -0.0271 & 0.0327 \\
\hline Spain & IBEX I & IBEX 35 INDEX & -0.0014 & 0.0249 & -0.0582 & 0.0470 \\
\hline United Kingdom & UKX & FTSE 100 INDEX & 0.0169 & 0.0312 & -0.0052 & 0.0389 \\
\hline
\end{tabular}

The Table presents the national stock market indices along with descriptive statistics of the mean adjusted abnormal return $(C A R)$ in the event window $[t, t+1]$ for each index for event and matched non-event days during the sample period (July 2006 to November 2014).

Denmark and Sweden are included in the analysis of Section 5.1, but not in Sections 5.2 and 5.3. 